Dzieje Najnowsze, Rocznik LIII - 2021, 1

PL ISSN 0419-8824

\author{
Rafał Wnuk \\ https://orcid.org/0000-0002-8526-7905 \\ Katolicki Uniwersytet Lubelski
}

\title{
Niedokończone scalenie. Próby włączenia Narodowych Sił Zbrojnych do Sił Zbrojnych w Kraju
}

\begin{abstract}
Abstrakt: W wyniku scalenia do Armii Krajowej weszły niemal wszystkie liczące się formacje zbrojne. Wyjątkiem były Armia Ludowa i Narodowe Siły Zbrojne-Związek Jaszczurczy NSZ-ZJ). Analiza zgromadzonego materiału prowadzi do wniosku, że NSZ-ZJ nie stały się częścią Sił Zbrojnych w Kraju z powodów ideologicznych (wrogość radykalnych nacjonalistów do demokracji i parlamentaryzmu), psychologicznych (ambicje przywódców NSZ-ZJ) i fundamentalnego konfliktu celów (nacjonalistyczni radykałowie dążyli do narodowej rewolucji, przywódcy AK zaś do restytucji II RP).
\end{abstract}

Słowa kluczowe: Armia Krajowa (AK), Grupa „Szańca”, Narodowe Siły Zbrojne (NSZ), Obóz Narodowo-Radykalny ABC (ONR ABC), Polskie Państwo Podziemne (PPP), Związek Jaszczurczy (ZJ), Związek Walki Zbrojnej (ZWZ).

Abstract: As a result of consolidation, the Home Army absorbed almost all major armed formations. The only exceptions were the People's Army and the National Armed Forces-the Lizard Union (NSZ-ZJ). An analysis of the gathered material leads to the conclusion that NSZ-ZJ did not become part of the Home Army for ideological reasons (hostility of radical nationalists to democracy and parliamentarism), psychological causes (ambitions of NSZ-ZJ leaders), and a fundamental conflict of goals (nationalist radicals strove for a national revolution, while the Home Army leaders wanted the restitution of the Second Polish Republic).

Key w or d s: Home Army (AK), Group 'Szaniec', National Armed Forces (NSZ), ABC National-Radical Camp (ONR ABC), Polish Underground State (PPP), Lizard Union (ZJ), Union for Armed Struggle (ZWZ). 
Scalenie Narodowych Sił Zbrojnych (NSZ) z Armią Krajową (AK) było dotychczas głównie przedmiotem zainteresowania badaczy zajmujących się historia $\mathrm{NSZ}^{1}$. To sytuacja o tyle zrozumiała, że dla NSZ próba przyłączenia się do Polskich Sił Zbrojnych (PSZ) w Kraju okazała się punktem zwrotnym, wydarzeniem, które doprowadziło do rozpadu organizacji. Historyków tych interesowała więc perspektywa NSZ rywalizujących wewnątrz organizacji frakcji. Punkt widzenia władz polskich na uchodźstwie, przywódców Polskiego Państwa Podziemnego (PPP) i dowództwa AK był dla nich jedynie punktem odniesienia do dziejów NSZ. W tekście niniejszym proponuję uzupełnienie tej perspektywy o to, jak widzieli zjednoczenie przywódcy polscy w Londynie, liderzy PPP i komendant AK. By osiagnaćc ten cel, konieczne jest cofnięcie się do pierwszych miesięcy II wojny światowej.

13 XI 1939 r. premier i Naczelny Wódz gen. Władysław Sikorski rozwiązał Służbę Zwycięstwu Polski (SZP) - pierwszą ogólnopolską organizację konspiracyjną utworzoną w okupowanym kraju. SZP łączyła funkcje podziemnego wojska, tajnej administracji i reprezentacji politycznej. Generał Sikorski premier rządu na uchodźstwie i wódz naczelny w jednej osobie - widział w SZP twór zdominowany przez sanatorów, w jego przekonaniu ludzi nieprzychylnych jego linii politycznej i jemu osobiście. Po otrzymaniu, w listopadzie 1939 r. od gen. Michała Tokarzewskiego, raportu o powołaniu SZP gen. Sikorski nakazał natychmiastowe zlikwidowanie tej organizacji, a w jej miejsce utworzył Związek Walki Zbrojnej (ZWZ), na którego komendanta mianował gen. Kazimierza Sosnkowskiego. Premier nie chciał, by powstające w okupowanym kraju podziemie stało się w przyszłości samodzielnym, alternatywnym wobec jego rządu, ośrodkiem politycznym. Z tej przyczyny nadał ZWZ charakter czysto wojskowy, z gruntu apolityczny i poddał go ścisłemu nadzorowi rządu.

Utrzymaniu kontroli służyło umieszczenie siedziby dowódcy ZWZ i jego sztabu we Francji. Pod okupacją działać miały wyłącznie dowództwa obszarów

\footnotetext{
${ }^{1}$ Listę monografii, których autorzy zajęli się scaleniem NSZ z AK, otwiera przełomowa, powstała na emigracji, praca Zbigniewa S. Siemaszki, Narodowe Sity Zbrojne, Londyn 1982. Kolejnym krokiem było wydanie przez Leszka Żebrowskiego trzech tomów źródeł do historii NSZ. Kwestia scalenia została poruszona we wstępach do tomów II i III. Bardzo ważnym momentem było pojawienie monografii Krzysztofa Komorowskiego, Polityka $i$ walka. Konspiracja zbrojna ruchu narodowego 1939-1945, Warszawa 2000. W książce zostały wykorzystane źródła z archiwów krajowych i zagranicznych. Temat scalenia został podjęty też w pracy Wojciecha J. Muszyńskiego, Duch młodych. Organizacja Polska i Obóz Narodowo-Radykalny w latach 1934-1944. Od studenckiej rewolty do konspiracji niepodlegtościowej, Warszawa 2011. W pisanej z pozycji apologetycznych pracy autor przeanalizował motywy działań przywódców środowiska ONR-OP. Niczego natomiast do naszej wiedzy o scaleniu nie wniosła najnowsza monografia NSZ Michała Gniadka-Zielińskiego, Narodowe Sity Zbrojne 1942-1947, Warszawa 2017. Bezrefleksyjna identyfikacja autora z przedmiotem badań i brak krytycyzmu powoduja, iż praca ta sytuuje się niebezpiecznie blisko nurtu hagiograficznego i nie sposób jej traktować jako monografii naukowej.
} 
ZWZ2 ${ }^{2}$ Rozwiązanie to winno zapobiec wypromowaniu osób i wykształceniu się ośrodków mogących w przyszłości rywalizować z gen. Sikorskim. Szybko okazało się, że skuteczne dowodzenie podziemiem z Francji jest niemożliwe i w styczniu 1940 r. powołano dwie komendy ZWZ w kraju, jedna na teren okupacji niemieckiej z siedzibą w Warszawie, drugą na teren okupacji radzieckiej „z siedzibą we Lwowie lub Wilnie”. Ponieważ tej ostatniej nie udało się zorganizować, faktycznym centrum kierowania ZWZ stała się Warszawa. Po upadku Francji było jasne, że okupacja nie zakończy się szybko. Dopiero wówczas, po przeniesieniu się rządu polskiego do Londynu, gen. Sikorski zdecydował się na likwidację emigracyjnego dowództwa ZWZ i wzmocnienie pozycji dowódcy konspiracji w kraju gen. Stefana Roweckiego „Grota”. 30 VI 1940 r. mianował go Komendantem Głównym ZWZ, zaś od września 1941 r. Komendant Główny ZWZ (później AK) nazywany był też Dowódcą Sił Zbrojnych w Kraju.

Wytyczne Naczelnego Wodza, dotyczace tworzenia podziemia zbrojnego, stawiały sprawę jasno: „ośrodkiem dyspozycji wojskowej, może być tylko jedna organizacja o charakterze najściślejszym, to jest ZWZ, której musza podporządkować się wszystkie inne organizacje wojskowe. Jedną z dróg podporządkowania jest przyjęcie do ZWZ komend wzgl. kierowniczych ośrodków innych organizacji”" ZWZ otrzymał więc od rządu w Londynie monopol na organizowanie oporu zbrojnego. Gdy dodamy do tego odziedziczona po SZP doświadczoną kadrę oficerską i sprawną sieć łączności, stanie się jasne, czemu z miejsca zaczął on pełnić rolę silnego magnesu przyciagającego inne grupy konspiracyjne. Mniejsze organizacje podziemne o charakterze wojskowym z reguły szybko podporządkowywały się ZWZ. Traciły niezależność, ale w zamian stawały się częścia PSZ, za którymi stał autorytet najwyższych władz polskich. Lokalni dowódcy byli włączani do istniejących już sztabów ZWZ lub zostawali komendantami nowo tworzonych jednostek podziemnej armii. Zdecydowanie większe problemy stwarzały bojówki afiliowane przy silnych stronnictwach politycznych ${ }^{6}$. $\mathrm{Z}$ jednej strony partie traktowały

${ }^{2}$ Instrukcja osobista i tajna dla komendanta baz nr II Komendanta Głównego ZWZ gen. K. Sosnkowskiego do płk. S. Rostworowskiego z 30 listopada 1939 r., w: Armia Krajowa $w$ dokumentach 1939-1945, t. I, cz. 1: Wrzesień 1939 - czerwiec 1941, Warszawa 2015, s. 85.

${ }^{3}$ Instrukcja nr 2 dla obyw. Rakonia (Grabicy) Komendanta Głównego ZWZ gen. K. Sosnkowskiego z 16 stycznia 1940 r., w: Armia Krajowa $w$ dokumentach..., t. I, cz. 1 (dalej: Instrukcja nr 2 dla obyw. Rakonia (Grabicy), s. 175.

${ }^{4}$ Komenda Główna ZWZ funkcjonująca na uchodźstwie została rozwiązana 29 VI $1940 \mathrm{r}$. Rozkaz wewnętrzny gen. Kazimierza Sosnkowskiego, 29 czerwca 1940 r., w: Armia Krajowa w dokumentach..., t. I, cz. 1, s. 464.

${ }^{5}$ Instrukcja nr 2 dla obyw. Rakonia (Grabicy), s. 177.

${ }^{6}$ Dylematy partii politycznych współtworzących PPP związane ze scaleniem dobrze ilustruje przykład Stronnictwa Ludowego. Ludowcy podzielili stworzone przez nich Bataliony Chłopskie na podziemną policję - Ludową Straż Bezpieczeństwa (LSB) oraz wojskowe Oddziały Taktyczne. Scaleniu z AK podlegała wyłącznie część wojskowa, natomiast jednostki LSB funkcjonowały w ramach Delegatury Rządu na Kraj. Tym sposobem część ich „wojskówki” 
swoje „wojskówki” jako monetę przetargową w walce o wpływy w ramach PPP, z drugiej zaś część dowódców tychże uważała, iż wyznawana przez nich ideologia ma większą wartość niż potrzeba scalenia wysiłku zbrojnego $\mathrm{w}$ ramach jednej organizacji lub jest nie do pogodzenia z celami stawianymi przez ZWZ. Tę ostatnią postawę reprezentowali podporządkowani Kremlowi polscy komuniści, których cele polityczne były w sprzeczności z celami rządu na uchodźstwie. $Z$ tej przyczyny rozmowy mające doprowadzić do włączenia Gwardii Ludowej (GL) do ZWZ zakończyły się fiaskiem.

Poza cywilnymi i politycznymi strukturami Polski Podziemnej znalazła się też konspiracja Obozu Narodowo-Radykalnego ABC (ONR ABC), występująca podczas okupacji jako Grupa „Szańca”. Radykalni nacjonaliści deklarowali co prawda uznanie dla rządu na uchodźstwie, ale jednocześnie występowali przeciwko wszystkim jego organom w okupowanym kraju. Strategia ta była następstwem wyznawanej przez nich radykalnie antydemokratycznej ideologii zakładającej przeprowadzenie „narodowej rewolucji”, w której wyniku miało powstać „Katolickie Państwo Narodu Polskiego” rządzone przez nacjonalistyczną monopartię. W konsekwencji bojówka Grupy „Szańca” - Organizacja Wojskowa Zwiazek Jaszczurczy (OW ZJ), tak jak komunistyczna GL, pozostawała poza ZWZ.

Złożony stosunek do akcji scaleniowej prezentowały Stronnictwo Narodowe (SN) i jego Narodowa Organizacja Wojskowa (NOW). Już w pierwszych miesiącach okupacji $\mathrm{w}$ łonie stronnictwa pojawiły się dwa podejścia do tej kwestii. W myśl pierwszego SN winno dążyć do szybkiego, pełnego scalenia NOW z ZWZ, by podziemne wojsko osiagnęło możliwie największą zdolność przed planowanym powstaniem powszechnym, które wobec spodziewanej klęski Niemców w wojnie z Francją i Wielką Brytanią miało się rozpocząć już w 1940 r. Członkowie NOW tym samym zyskaliby możliwość oddziaływania „w duchu narodowym” na żołnierzy ZWZ. W myśl drugiego podejścia SN winno stworzyć własne ugrupowanie zbrojne niezależnie od ZWZ i miałoby ono włączyć się do walk powstańczych, ale jako formacja podporządkowana Naczelnemu Wodzowi, a nie podlegajaca komendantowi ZWZ. Działacze narodowi prezentujący ten sposób myślenia otwarcie wyrażali nieufność do ZWZ, który uważali za opanowany przez piłsudczyków ukrywających pod maska profesjonalnych wojskowych ambicję zdobycia władzy w powojennej Polsce $^{7}$. Deklarowali oni udział w pracach cywilnych i politycznych PPP przy jednoczesnej odmowie włączenia NOW do „sanacyjnej” ZWZ.

W pierwszych miesiacach okupacji w SN przewagę posiadali zwolennicy wejścia do ZWZ ${ }^{8}$. Szybki upadek Francji doprowadził do zmiany nastrojów

znalazła się poza strukturami Wojska Polskiego i w dalszym ciagu podlegała kierownictwu partii politycznej, pozostając jednocześnie policyjno-porządkowym organem PPP.

7 K. Komorowski, Polityka i walka..., s. 223-226.

${ }_{8}$ Zwolennikami szybkiego scalenia byli pierwsi przedstawiciele SN w Politycznym Komitecie Porozumiewawczym przy ZWZ: Leon Nowodworski, Witold Staniszkis i Aleksander Dębski. 
i w drugiej połowie 1940 r. wzmocniły się pozycje przeciwników scalenia, których liderem był ówczesny p.o. prezesa partii, Mieczysław Trajdos. Spory wewnątrz SN i NOW utrudniały negocjacje z ZWZ. W maju 1941 r. Trajdos został aresztowany przez Niemców. Nowym prezesem SN został zwolennik scalenia Stefan Sacha. Według prowadzącego negocjacje z ramienia ZWZ płk. Tadeusza Komorowskiego postawa Sachy walnie przyczyniła się do sukcesu negocjacji ${ }^{9}$.

3 IX 1941 r. gen. Sikorski wydał dotyczacy akcji scaleniowej kolejny rozkaz, w którym napisał, że organizację wojskową w kraju uznaje „za główną część dowodzonych przeze mnie sił zbrojnych”. We wcześniejszych dokumentach określał on ZWZ mianem „składowej sił zbrojnych Rzeczypospolitej”. To było ważne przesunięcie akcentów, wskazujące na wzrost znaczenia organizacji zbrojnej w okupowanym kraju. Sikorski podkreślił, iż „ugrupowania wojskowe separujące się lub opozycyjne” należy podporządkować komendantowi ZWZ „wszelkimi środkami”. Z uwagi na partyjny często charakter niepodporządkowanych „wojskówek” zobowiązywał on Delegata Rządu do udzielenia „w tej sprawie najdalej idącej pomocy Komendantowi ZWZ, wpływając na odpowiednie organizacje polityczne, które organizują lub popieraja odrębne grupy wojskowe". Rozkaz zabraniał ponadto jakiegokolwiek wspierania materialnego niezrzeszonych organizacji z funduszy przesyłanych do kraju i kolejny raz podkreślał „bezwzględny nakaz” odseparowania ZWZ od partii politycznych ${ }^{10}$. Pół roku później, rozkazem z dnia 14 II 1942 r., gen. Sikorski przemianował ZWZ na AK. Organizacja przestawała być „związiem”, a stała się „armią. Ta semantyczna zmiana miała duże znaczenie symboliczne i konsekwencje praktyczne. Dowódcy wszystkich niescalonych wojskowych „organizacji, związków, zrzeszeń” czy „grup” musieli tłumaczyć podkomendnym, dlaczego nie sa żołnierzami armii polskiej, lecz bojownikami tego czy innego stronnictwa politycznego.

Tak atmosfera, jak sytuacja prawna, wytworzone przez powyższe rozkazy, wpływały na przebieg negocjacji między ZWZ-AK a SN i NOW. W marcu 1942 r. do Warszawy przybył cichociemny, oficer łącznikowy Naczelnego Wodza płk Józef Spychalski. Na początku kwietnia podjął on rozmowy z Sacha, z którym wypracował zasady włączenia NOW do AK. 3 maja odbyło się przełomowe spotkanie. Prezes SN w obecności komendanta AK gen. Roweckiego podją ostateczną decyzję o scaleniu NOW z AK. Następnego dnia miała miejsce odprawa Komendy Głównej (KG) NOW, w której trakcie Sacha poinformował o scaleniu oficerów NOW. Większość członków komendy oprotestowała decyzję prezesa, natomiast Komendant Główny NOW ppłk Józef Rokicki „Karol” i jego najbliżsi współpracownicy ją poparli. Powołano

9 T. Bór-Komorowski, Armia Podziemna, Londyn 1952, s. 91.

${ }^{10}$ Londyn, dnia 3 września 1941 r. Warski Kalina, podpisano Sikorski Gen. Broni, Premier i WNWP, w: Armia Krajowa w dokumentach..., t. II, cz. 1: Wrzesień 1939 - czerwiec 1941, Warszawa 2019, s. 133. 
wówczas czteroosobową komisję wspólna, do której z ramienia AK weszli płk Stanisław Rostworowski „Rola”, płk Antoni Sanojca „Kortum”, NOW zaś ppłk Rokicki i por. Stefan Klimecki „Baca”. Ich zadaniem było przygotowanie scalenia od strony praktycznej. Jako że do komisji weszli oficerowie NOW przychylni scaleniu, prace przebiegały sprawnie. Natomiast w KG NOW sprawa wywołała ostre podziały. Przeciwnicy zjednoczenia używali argumentów, iż AK jest „podziemną armią sanacyjną” i krytykowali zwolenników scalenia za „ugodę z sanacją. Zwolennicy zaś podnosili argument konieczności ,jedności narodowej" w walce z okupantem i odwoływali się do żołnierskiego obowiązku służby ojczyźnie ${ }^{11}$. Prowadzone na łamach centralnej podziemnej prasy SN spory błyskawicznie przeniosły się do terenowych ogniw NOW.

7 VII 1942 r. przeciwnicy scalenia (frondyści) powołali Tymczasową Komisję Rządzącą SN i ogłosili przejęcie władzy nad partią i NOW. Podjęli też na łamach wydawanych przez nich gazet akcję mającą na celu skompromitowanie statutowych władz SN. Nie poprzestali na pogróżkach i ogłosili nawet „wyroki” na niektórych adwersarzach. W odpowiedzi prawowici przywódcy SN-NOW zapowiedzieli zgłoszenie sprawy do podziemnego sądu. Konflikt w łonie SN przerodził się w otwarty rozłam.

Reprezentująca frondystów Tymczasowa Komisja Rządząca SN w komunikacie nr 1 z 7 VII 1942 r. ogłosiła, iż zamierza „zgodnie z dotychczasowa linia polityczna obozu [...] kontynuować pracę nad organizacja SN oraz zdecydowanie zwalczać wszelkie próby uzależnienia narodowych sił zbrojnych od wojskowej emanacji sanacji t.j. PZP/ZWZ"12. W pierwszym wydanym przez nich dokumencie otwarcie sprzeciwili się więc decyzjom podjętym przez premiera polskiego rządu na uchodźstwie, Naczelnego Wodza i Komendanta Głównego AK. Jednostki Wojska Polskiego (WP) w kraju nazwali „emanacją sanacji” i zapowiedzieli utrzymanie całkowicie niezależnych od ZWZ-AK „narodowych sił zbrojnych". W dokumencie tym prawdopodobnie po raz pierwszy użyto tego określenia, które później, pisane wielkimi literami, stało się nazwą narodowo-radykalnej „wojskówki”.

15 VIII 1942 r. gen. Sikorski wydał rozkaz nr 3326, w którego świetle na sprzeciwiających się scaleniu frondystów spadała odpowiedzialność za niewykonanie polecenia Naczelnego Wodza ${ }^{13}$. Nakazywał on wszystkim orga-

${ }^{11}$ K. Komorowski, Polityka i walka..., s. 234-235; S. Żochowski, O Narodowych Siłach Zbrojnych. NSZ, Lublin 1994, s. 104-105; Z.S. Siemaszko, op. cit., s. 47.

${ }^{12}$ Cyt. za: J.J. Terej, Rzeczywistość i polityka. Ze studiów nad dziejami najnowszymi Narodowej Demokracji, Warszawa 1979, s. 264.

13 Treść rozkazu nr 3326 Naczelnego Wodza i Ministra Spraw Wojskowych gen. W. Sikorskiego w sprawie podporządkowania organizacji wojskowej w Kraju Dowódcy Armii Krajowej z 15 VIII 1942 r.: „1. Wszystkie organizacje wojskowe, istniejące na terenie Kraju, których celem jest współdziałanie w walce $\mathrm{z}$ nieprzyjacielem lub w pomocniczej służbie wojskowej podporządkowuję Dowódcy Armii Krajowej.

2. Zależnie od charakteru organizacji Dowódca Armii Krajowej 
nizacjom zbrojnym w kraju bezwzględne podporządkowanie się komendantowi AK i zabraniał żołnierzom AK równoległej przynależności do jakichkolwiek innych organizacji o charakterze militarnym. Jedynie pkt 2 rozkazu pozostawiał pole do interpretacji, gdyż dawał komendantowi AK wybór „całkowitego” lub „częściowego” (,pozostawiającego dotychczasowy charakter organizacji”) scalenia z AK. Do zapisu tego odwoływali się później przywódcy ugrupowań dążący do zachowania autonomii, z reguły pomijali oni, iż ten punkt rozkazu wyraźnie mówił, iż to wyłącznie komendant AK decyduje o tym, jaki charakter ma przyjać scalenie. Na interpretację rozkazu przez dowództwo AK wpływały liczne wcześniejsze wytyczne, jednoznacznie nakazujace budowę „całkowicie jednolitych sił zbrojnych”.

Lojalni wobec PPP działacze SN zastosowali się do rozkazu Naczelnego Wodza. 4 XI 1942 r. gen. Rowecki odebrał od komendanta NOW ppłk. Rokickiego przysięgę, rozpoczynając faktyczne włączanie NOW w szeregi AK, dwa tygodnie później zaprzysiężeni zostali komendanci okręów NOW ${ }^{14}$.

Secesjoniści, wśród których rolę nieformalnego lidera odgrywał Zbigniew Stypułkowski, podjęli rozmowy z wywodzącą się z ONR ABC Grupa „Szańca” i kilkoma marginalnymi grupami podziemnymi. Ramieniem zbrojnym Grupy „Szańca” była OW ZJ. Jak zauważył Krzysztof Komorowski, rokowania prowadzili przywódcy polityczni, którzy od początku zakładali utrzymanie odrębności organizacji partyjnych i dążyli wyłącznie do połączenia grup militarnych. Pertraktacje doprowadziły do utworzenia, głównie w oparciu o niescaloną część NOW i OW ZJ, organizacji NSZ, o czym informował rozkaz z 20 IX 1942 r., podpisany przez wyznaczonego na Dowódcę NSZ dotychczasowego członka KG NOW płk. Ignacego Oziewicza „Czesława”. Równolegle swój rozkaz o utworzeniu NSZ ogłosił komendant ZJ por. Władysław Marcinkowski „Jaxa”15.

a. albo zarządza całkowite lub częściowe wcielenie do Armii Krajowej,

b. albo pozostawia dotychczasowy charakter określając stopień podporządkowania.

3. Dowódca Armii Krajowej zapewni organizacjom tym wszelka pomoc i środki [...] w ilościach ustalonych przez niego i przy uwzględnieniu jego możliwości.

4. W skład organizacji niewcielonych do Armii Krajowej moga wchodzić żołnierze Armii Krajowej tylko za specjalnym zezwoleniem Dowódcy Armii Krajowej

5. Organizacje wojskowe uchylające się od podporządkowania Dowódcy Armii Krajowej nie będą uznawane przez Władze Polskie. Udział żołnierzy Armii Krajowej w takich organizacjach jest zakazany.

6. Żołnierze Armii Krajowej, którzy pomimo zakazu będą nadal należeli do nieuznawanej przez Dowódcę organizacji wojskowej zostaną pociagnięci do odpowiedzialności sądowo-karnej. 7. Dowódca Armii Krajowej w sprawach związanych z wykonaniem powyższego rozkazu, otrzyma od Delegata Rządu wszelką możliwą pomoc”. Armia Krajowa w dokumentach..., t. II, cz. 2: Wrzesień 1939 - czerwiec 1941, Warszawa 2019, s. 559-560.

141942 listopad 24, Warszawa - Gen. Rowecki do Centrali: Stronnictwo Narodowe podporządkowało swą organizację wojskowa, scaleniowej, w: Armia Krajowa w dokumentach..., t. II, cz. 2, s. 700 .

${ }^{15}$ Por. Władysław Marcinkowski „Jaxa” w NSZ występował jak podpułkownik. 
Według Zbigniewa Siemaszki secesjoniści dostrzegli w działaczach Grupy „Szańca” duży potencjał wynikający z ich młodzieńczego zapału, dynamizmu i ofiarności. Natomiast ONR-owcy w osobie doświadczonego i błyskotliwego Stypułkowskiego znaleźli „wreszcie to, czego im brakowało a mianowicie przywódcę”. Historyk ten podkreślił, że między środowiskiem Grupy „Szańca” a Stypułkowskim i jego zapleczem „Od początku istniała pewna rozbieżność. Stypułkowski, mając za sobą doświadczenia współpracy z innymi ugrupowaniami politycznymi, zdawał sobie sprawę, iż to, co może osiagnać i na co można liczyć, to jedynie wpływ na decyzje kierownictwa krajowego. Natomiast Grupa Szańca, z natury swej bezwzględna i nie skłonna do kompromisu, ale do rozwiązań krańcowych, nie miała za sobą doświadczenia współpracy z innymi ugrupowaniami politycznymi" ${ }^{\prime 16}$.

Wydany 2 X 1942 r., powołujący oficerów sztabu NSZ, „Rozkaz nr 2” płk Oziewicz zaczął od słów: „Żołnierze: W chwili obecnej Armia Polska znajduje się poza granicami kraju. Wy zatem, nie mogąc czynnie walczyć w jej szeregach zgrupowani zostaliście w organizacji Narodowych Sił Zbrojnych"17. Następnego dnia przesłał do gen. Roweckiego pismo powiadamiające o powołaniu NSZ, w którym wyrażał „wolę podjęcia rozmów celem uregulowania zależności NSZ od Komendanta S[ił] Z[brojnych] w Kraju"18. Tak więc w ciagu 48 godzin komendant NSZ płk Oziewicz wydał wzajemnie wykluczające się dokumenty. Gdy informował podkomendnych o powstaniu NSZ, twierdził, że w okupowanym kraju nie działa „Armia Polska”. Znał wówczas rozkazy Naczelnego Wodza dotyczace ZWZ i AK, nakazujace scalenie armii w ramach AK. Co więcej, w liście do komendanta AK - a więc dowódcy rzekomo nieistniejącej w okupowanym kraju „Armii Polskiej” - deklarował chęć rozmów scaleniowych. Oziewicz pisząc, jakoby PSZ istniały wyłącznie na uchodźstwie, wprowadzał podległych mu ludzi w błąd.

Propaganda NSZ od początku negowała fakt, iż w świetle obowiązującego w II RP prawa jedynie AK była WP w kraju. Rozkazy i wydawnictwa przekonywały, jakoby formalne umocowanie NSZ i AK było identyczne, z tym że AK nie dość, iż miała sanacyjny charakter, to ulegała wpływom komunistycznym. NSZ natomiast prezentowała się jako jedyna prawdziwie narodowa siła zdolna przeciwstawić się komunistycznemu zagrożeniu, krocząca własna, niezależną drogą ku Wielkiej Polsce Katolickiej. Taki przekaz był kierowany w dół - do własnych szeregów i wszystkich odbiorców prasy NSZ. Radykalnie odmienne sygnały kierowano w górę do władz polskich na uchodźstwie. Dowództwo NSZ zapewniało, że jest

\footnotetext{
${ }_{16}$ Z.S. Siemaszko, op. cit., s. 57.

${ }^{17}$ Rozkaz nr 2, 2 X 1942 r., syngowany: Dowódca NSZ „Czesław” (I. Oziewicz), fotokopia, w: K. Komorowski, Polityka i walka..., aneks, s. nlb.

${ }^{18}$ Oświadczenie „Tadeusza”, „Czempa” i „Władysława” z 3 X 1943 w sprawie pertraktacji scaleniowych, fotokopia, w: K. Komorowski, Polityka i walka..., s. 394.
} 
gotowe scalić się z AK, a na przeszkodzie stoją niezrozumiałe uprzedzenia ze strony KG AK.

Zasadniczym problemem NSZ pozostawał brak jednolitego kierownictwa politycznego. Działaczy Grupy „Szańca” i frondystów z SN oddzielała ideologiczna przepaść. Pierwsi byli zwolennikami systemu totalitarnego i bezkompromisowymi przeciwnikami „sanacyjnej” AK. Zakładali, iż scalenie powinno się odbyć jako krok na drodze do „narodowej rewolucji”, w której ramach narodowi radykałowie uzyskaliby decydujacy wpływ na AK. Drudzy nie akceptowali proponowanych przez AK zasad scalenia, lecz nie odrzucali pluralizmu politycznego i dążyli do włączenia się w struktury PPP na możliwie najlepszych dla nich warunkach. Rolę nieformalnego przywództwa NSZ odgrywała trójka polityków secesjonistów SN: Zbigniew Stypułkowski, August Michałowski, Karol Stojanowski i trójka z grupy Grupy „Szańca”: Władysław Marcinkowski, Jerzy Olgierd Iłłakowicz i Otmar Wawrzkowicz. Gdy opadła euforia pierwszego okresu, powróciły uprzedzenia i pojawiła się wzajemna nieufność. Obie grupy rywalizowały o wpływy w terenie. Podział okazał się tak głęboki, że wiosna 1943 r. organizacja stanęła na krawędzi rozpadu. 8 V 1943 r. w odpowiedzi na kryzys przedstawiciele obu ugrupowań politycznych zawarli kompromis polegajacy na powołaniu czterdziestoosobowej Tymczasowej Narodowej Rady Politycznej (TNRP), której podporządkowano NSZ. Pracami TNRP kierowało ośmioosobowe prezydium, zaś tymczasowym przewodniczącym TNRP i sekretarzem generalnym prezydium został Stypułkowski.

Dowództwo AK podjęło rozmowy z politycznym kierownictwem NSZ. Głównym warunkiem narodowców było uzyskanie szerokiej autonomii w ramach AK. Ich zdaniem scalenie powinno sprowadzić się do nominacji Dowódcy NSZ na zastępcę komendanta AK. Koncepcja znalazła odzwierciedlenie w Deklaracji NSZ z lutego 1943 r., głoszącej, iż co prawda NSZ „dążą do scalenia akcji wojskowej w kraju pod rozkazami komendanta Sił Zbrojnych w Kraju”, lecz zadania „zawarte w Deklaracji NSZ oraz względy konspiracyjne uzasadniaja zachowanie odrębności oddziałów NSZ w ramach Sił Zbrojnych w Kraju". Dokument głosił, że to NSZ sa „zawiązkiem przyszłej Armii Narodowej”, a ich misja to kierowanie „zbiorowym oporem społeczeństwa” ${ }^{19}$.

NSZ zatem rościły sobie prawo do kierowania oporem w kraju, co było otwartym podważeniem roli agend PPP. Zapowiedź tworzenia „Armii Narodowej”, przy jednoczesnym przemilczeniu AK, musiała być potraktowana przez dowództwo tej ostatniej jako celowe sabotowanie rozkazów Naczelnego Wodza. W tej sytuacji to, że gen. Tadeusz Komorowski - główny negocjator z ramienia komendanta AK - odrzucił postulaty przedstawicieli NSZ, nie mogło być zaskoczeniem ${ }^{20}$.

${ }^{19}$ Narodowe Sity Zbrojne. Deklaracja NSZ, w: Narodowe Sity Zbrojne. Dokumenty, struktury, personalia, [t. I], oprac. L. Żebrowski, Warszawa 1996, s. 30-31.

${ }^{20}$ K. Komorowski, Jeden $z$ „Szesnastu”: okupacyjny watek biografii Zbigniewa Styputkowskiego, „Niepodległość i Pamięć” 2017, nr 1 (57), s. 26-29. 
Wobec stanowiska strony AK-owskiej reprezentanci NSZ podjęli próbę ominięcia KG AK i w końcu 1942 r. zwrócili się o poparcie ich stanowiska do Delegata Rządu na Kraj Jana Piekałkiewicza. Ten nie udzielił lub nie zdążył udzielić im odpowiedzi, bo w lutym 1943 r. został aresztowany. Jego następca, Jan Stanisław Jankowski w marcu 1943 r. do sprawy odniósł się jednoznacznym oświadczeniem:

Mimo że rozporządzenia Pana Premiera, rozkazy Naczelnego Wodza i Komendanta Sił Zbrojnych w Kraju oraz moje oświadczenia dostatecznie już wyjaśniły, jak zostało uregulowane scalenie wysiłków wojskowych w Kraju i komu zostało powierzone dowodzenie, dotychczas jeszcze są próby siania w tej dziedzinie zamętu. Ostatnim wydarzeniem takim jest utworzenie samozwańczej komendy „Narodowych Sił Zbrojnych”, której rozkazy obliczone są na wywołanie wrażenia, że stosunki rozkazodawcze w dziedzinie wojskowej w Kraju sa jeszcze płynne. [...] Z ramienia Naczelnego Wodza i Ministra Obrony Narodowej wszystkie sprawy wojskowe w Kraju reguluje Komendant Sił Zbrojnych w Kraju; wszelkie przeciwstawianie się powyższemu jest robotą szkodliwą i zasługującą na potępienie ${ }^{21}$.

Polityczne kierownictwo NSZ uzyskało efekt odwrotny do zamierzonego. Zamiast wzmocnienia własnych pozycji negocjacyjnych otrzymali od najwyższego przedstawiciela rządu RP w okupowanym kraju potwierdzenie, iż ich obowiązkiem jest podporządkowanie się AK, do tego dowódcy NSZ zostali nazwani szkodliwymi, zasługującymi na potępienie samozwańcami.

Wiosną 1943 r. w wydawnictwach radykalnej prawicy ukazały się artykuły głoszące „anachronizm” i „zmurszałość partyjnych porozumień” stanowiących fundament PPP. Autorzy tych tekstów odrzucali demokrację parlamentarną za jej jakoby „żydomasoński rodowód”. Tradycyjnie już dowódców AK oskarżano o „sanacyjność” i doprowadzenie do klęski we wrześniu 1939 r., nowościa było za to porównanie „propagandy Ludzi Wrześniowych” do metod Josepha Goebbelsa. NSZ przedstawiały siebie jako jedyna „prawdziwie niezależna” siłę reprezentująca polskie interesy narodowe ${ }^{22}$. KG AK oceniała: „Kierownictwo polityczne NSZ uzurpuje sobie samowolnie i bez podstaw prawa do reprezentowania przekonań całego odłamu społeczeństwa narodowo-demokratycznego i narodowo-radykalnego”, prasa NSZ zaś „zohydza w oczach społeczeństwa” AK i podważa jej mandat „do kierowania cała praca wojskową w Kraju” ${ }^{23}$. Przywódcy NSZ utrzymywali, iż w momencie wybuchu powstania powszechnego konieczne będzie istnienie dwóch odrębnych armii, przy czym zastrzegali, iż ich aktywność skupi się na ziemiach zachodnich. AK według nich winna

${ }^{21}$ Oświadczenie delegata rządu Jana Stanisława Jankowskiego opublikowane w: „Rzeczpospolita Polska”, 11 III 1943, nr 4-5 (53).

${ }_{22}$ B. Wójcik, ONR gra va banque. Zapomniany epizod schytku okupacji, http://ohistorie. eu/2018/09/28/626/ (dostęp: 6 I 2020).

${ }^{23}$ Studium Polski Podziemnej w Londynie (dalej: SPP), 434 A, NSZ, Akcja scaleniowa Organizacji Wojskowej w Kraju, 22.06.1943 r., Meldunek nr 202, k. 1. 
koncentrować swe działania w centrum i na wschodzie Polski. Aspiracje te miały odbicie w prasie organizacyjnej i rozkazach, gdzie nazw Narodowe Siły Zbrojne, Armia Narodowa i Armia Zachodnia używano często synonimicznie.

Z wojskowego punktu widzenia twierdzenie przywódców NSZ, jakoby rozproszenie sił zbrojnych i poddanie ich rozkazom dwóm niezależnym, dążącym do osiagnięcia odrębnych celów dowództwom jest rozwiązaniem optymalnym, lepszym od jednego dowództwa koordynującego całość sił, należy uznać za absurdalne. Dodać trzeba, że w szczytowym okresie rozwoju NSZ były sześciokrotnie mniejsze niż $\mathrm{AK}^{24}$, nie zbudowały struktur na ziemiach wschodnich II RP i nie posiadały uznania rządu na uchodźstwie. Z tej perspektywy twierdzenia strony NSZ-owskiej, jakoby zajmowały one na podziemnej scenie wojskowej i politycznej pozycję równorzędną z PPP-AK, a ideowo nad nim górowały, należy uznać za równie uzasadnione jak podobne enuncjacje Polskiej Partii Robotniczej (PPR)-Armii Ludowej (AL). Strona akowska stanowisko prezentowane przez NSZ określała jako „demagogię” i „warcholstwo”.

Mimo wzajemnych oskarżeń po kilkumiesięcznej przerwie strony powróciły do rozmów. Gdy 31 III 1943 r. spotykali się gen. Rowecki i płk Oziewicz, sytuacja na froncie uległa zasadniczej zmianie w stosunku do końca 1942 r., kiedy to negocjacje zamarły. Po niemieckiej klęsce pod Stalingradem najbardziej prawdopodobnym scenariuszem stało się nieodległe wyparcie Niemców z ziem polskich przez Armię Czerwona. Ewentualne scalenie musiało nastapić przed wkroczeniem Sowietów. Obie strony miały świadomość, że czasu na podjęcie decyzji pozostaje coraz mniej, a jednocześnie nikt nie mógł przewidzieć, kiedy front wschodni przesunie się na ziemie II RP. W tej sytuacji reprezentanci AK i NSZ wyrazili wolę kontynuowania rozmów i uzgodnili kalendarz pertraktacji.

Już po rozpoczęciu negocjacji, w drugiej połowie kwietnia 1943 r. gen. Rowecki wysłał do płk. Oziewicza pismo ostro piętnujące postępowanie NSZ. Napisał m.in.:

doszły do moich rąk oryginalne rozkazy poszczególnych Pańskich podwładnych ziejące nienawiścią i fałszywymi oskarżeniami pod adresem dowodzonych przeze mnie Sił Zbrojnych w Kraju. Stwierdzam, że nieprzytomna kampania prasowa organów reklamujących akcję tworzenia niezależnie ode mnie NSZ odgrywa tu znaczna a niechlubną i szkodliwą rolę. Okłamywanie opinii i jątrzenie szeregów przeszkadza wytworzeniu się atmosfery koniecznej do zakończenia scalania przez wcielenie w podległe mi szeregi również NSZ [...]. Fakt pozostawania NSZ na uboczu jest niedopuszczalny, a próby rozbijania jedności żołnierskiej w kraju przez prasę NSZ karygodne. Za przedłużanie tego stanu ponoszą odpowiedzialność tak wojskowi jak i polityczni kierownicy $\mathrm{NSZ}^{25}$.

${ }^{24}$ W 1944 r. AK liczyła 340-360 tys. żołnierzy, NSZ zaś 58-65 tys. członków.

${ }^{25}$ Komendant Sił Zbrojnych w Kraju „Grot” do „W. Pana Czesława”, 20 IV 1943 r., cyt. za: K. Komorowski, Polityka i walka..., s. 398. 
Prowadzone w takim klimacie rozmowy z trudem posuwały się do przodu. Oziewicz i Stypułkowski - od maja 1943 występujacy jako przewodniczacy TNRP - nieodmiennie deklarowali wolę zjednoczenia, które uzależniali od zagwarantowania NSZ niezależności w ramach $\mathrm{AK}^{26}$. Strona akowska zaś stała na stanowisku pełnej jedności sił zbrojnych i oczekiwała faktycznego, a nie jedynie formalnego scalenia. Trwająca do 1 VI $1943 \mathrm{r}$. tura negocjacji nie doprowadziła do zbliżenia stanowisk. W końcu czerwca Niemcy aresztowali płk. Oziewicza i gen. Roweckiego, co jednak nie wpłynęło na wzajemne relacje układających się stron.

Ambicje przywódców NSZ oddawał rozkaz z 29 VII 1943 r., informujący o aresztowaniu gen. Roweckiego, w którym czytamy: „Pamiętajmy, że w walce silniejszy ma zawsze obowiązek wesprzeć słabszego. Teraz pozostaliśmy na terenie Kraju jako najsilniejsza, nierozbita dotąd organizacja, obowiązkiem naszym jest nieść pomoc wszystkim, którzy jej potrzebuja”"27. Dokument ten sygnowany został pseudonimem płk. Oziewicza, którego aresztowano dwa dni przed komendantem AK i od miesiąca pozostawał w niemieckich rękach. Liderzy NSZ starali się więc ukryć informację o uwięzieniu własnego dowódcy i przedstawić swą organizację jako najsilniejsza, posiadająca sprawnie funkcjonujace przywództwo, AK zaś jako siatkę rozbita, potrzebująca wsparcia i opieki ze strony „silniejszych” NSZ. Tymczasem było dokładnie odwrotnie. Dopiero 1 VIII 1943 r. członkowie TNRP wybrali na nowego Dowódcę NSZ płk. Tadeusza Kurcyusza „Żegotę”. 28 lipca - w dniu wydania rozkazu stanowisko NSZ pozostawało nieobsadzone. W AK natomiast już 1 lipca obowiązki komendanta przejął gen. Komorowski „Bór”, a KG AK działała bez żadnej przerwy.

Wybór płk. Kurcyusza znacząco komplikował i tak niełatwą już sytuację. Oficer ten był zaprzysiężonym członkiem AK i pełnił funkcję szefa komunikacji w KG ZWZ-AK. W sierpniu 1942 r. został aresztowany przez Niemców. W grudniu udało się go wykupić, po czym przeniesiono go do rezerwy personalnej KG AK. Po wyjściu z więzienia wstapił do NSZ, co ukrył przed przełożonymi. Tym samym złamał rozkaz Naczelnego Wodza z 15 VIII 1942 r., zakazujący członkom AK przynależności do innych organizacji wojskowych, w związku z czym podlegał odpowiedzialności karnosądowej. Nowy Dowódca NSZ starał się ukryć swą tożsamość, nie mógł więc reprezentować kierowanej przez siebie organizacji w rozmowach z delegatami KG AK. Gdy latem 1943 r. wrócono do rozmów, członkowie TNRP i sztabu NSZ próbowali zataić, kim jest oficer NSZ posługujący się pseudonimem „Żegota”. Do nowego komendanta AK,

\footnotetext{
${ }^{26}$ AK reprezentowali gen. Stefan Rowecki „Grot”, płk Stefan Rostworowski „Rola” i ppłk Antoni Sanojca „Kortum”, NSZ zaś, oprócz płk. Ignacego Oziewicza i Zbigniewa Stypułkowskiego, Władysław Marcinkowski, Tadeusz Salski i ks. Jan Salamucha.

${ }^{27}$ Pismo Dowódcy NSZ „Czesława” dotyczące stosunku od PZP, 29 VII 1943 r., cyt. za: K. Komorowski, Polityka i walka..., s. 399.
} 
gen. Komorowskiego „Bora” szybko dotarły informacje dotyczące płk. Kurcyusza. KG nie ujawniając swej wiedzy o roli płk. Kurcyusza w NSZ, zwróciła się do niego o powrót do służby. Ten zaś „na pisemny rozkaz złożył fałszywy meldunek, że jakoby pełnił rolę doradcy technicznego w Delegaturze na odcinku kolejnictwa, zatajając objęcie Dtwa NSZ" ${ }^{28}$. Komendant AK dysponował więc niezbitymi dowodami na to, iż płk Kurcyusz przeszedł do niebędącej częścia PSZ organizacji i z rozmysłem wprowadził w błąd swych przełożonych. Generał Komorowski uznał, że oficer wobec niego nielojalny, obciążony ciężkimi zarzutami, nie może odpowiadać za scalenie NSZ z AK. Przedstawiciele AK $\mathrm{w}$ trakcie negocjacji nie zdradzali jednak delegatom TNRP, iż znaja prawdziwe personalia nowego Dowódcy NSZ.

Do rozmów wrócono na przełomie lipca i sierpnia 1943 r. Reprezentanci TNRP-NSZ nie zmienili taktyki. Nieodmiennie deklarowali wolę scalenia, stawiając jednocześnie warunki nie do zaakceptowania przez AK. Generał Komorowski zdecydował się przerwać eneszetowską grę na czas i 31 VIII 1943 r. zameldował Naczelnemu Wodzowi:

Bardzo opornie rozwija się akcja scaleniowa NSZ. Kampania prasowa NSZ, zmierzająca do zohydzenia PZP ${ }^{29} \mathrm{w}$ oczach społeczeństwa, obecnie - na skutek mego kategorycznego rozkazu - ucichła w centralnych organach ich prasy, czasem jednak występuje złośliwie w organach prowincjonalnych. W rezultacie wyznaczyłem im ostateczny termin $15 \mathrm{X}$ br. do bezwzględnego podporządkowania się. W wypadku odmowy rozwiążę oddziały NSZ a oficerów powołam indywidualnie do służby czynnej ${ }^{30}$.

Wobec impasu 15 września komendant AK polecił reprezentującemu go AK płk. Rostworowskiemu przekazać rozmówcom sformułowane w tonie ultymatywnym warunki, w myśl których NSZ miało rozpocząć akcję scaleniowa najpóźniej 15 października. Zapowiedział też wyciagnięcie konsekwencji wobec osób odmawiających wykonania polecenia. Strona akowska przekazała przedstawicielom TNRP-NSZ projekt umowy przewidujący, że sformowane już plutony i kompanie NSZ zachowają swój skład i charakter. Jednostki większe - bataliony i pułki - nie będą mogły jednak mieć odrębnej tożsamości ideologicznej i staną się apolitycznymi oddziałami wojskowymi. Wymóg złożenia przysięgi AK przez oficerów NSZ nie był wyłącznie rytuałem, oznaczał on bowiem koniec działalności w „wojskówce”, a rozpoczynał okres służby w WP. Wszystkie uzyskane po 1939 r. awanse, patenty i odznaczenia miały podlegać weryfikacji i dostosowaniu do wymagań obowiązujących w AK.

28 SPP, A 434, NSZ, Załącznik do pisma do Pełnomocnika Rządu w Kraju z dn. 5 VII 1944 r. Gen. T. Komorowski do J.S. Jankowskiego, k. 54.

${ }^{29}$ PZP - Polski Związek Powstańczy - w okresie wojny nazwa ta była używana dla określenia ZWZ i AK.

${ }^{30}$ Meldunek organizacyjny Nr 220 za czas od 1 III 43 do 31 VIII 43 (gen. Komorowski do gen. Sosnkowskiego), w: Armia Krajowa w dokumentach..., t. III: Kwiecień 1943 - lipiec 1944, Warszawa 1990, s. 105. 
Projekt przewidywał, iż dozbrojenie i zaopatrzenie odbywać się będą według zasad w niej panujących. Narodowcy mieli zachować prawo do oddziaływania ideologicznego na wprowadzanych do AK eneszetowców, ale musieli też pozwolić na kolportaż prasy AK w oddziałach wywodzących się z NSZ. Projekt umowy zakładał wchłonięcie siatek NSZ przez $\mathrm{AK}^{31}$.

Dwa dni po otrzymaniu dokumentu przedstawiciele TNRP-NSZ zgłosili zastrzeżenia do przedstawionego im stanowiska i zażądali dla Dowódcy NSZ stanowiska zastępcy Komendanta Sił Zbrojnych w Kraju do spraw NSZ. 2 października odstapili oni od negocjacji i skierowali do komendanta AK oświadczenie zapowiadające, że odwołają się wprost do Naczelnego Wodza, aby bez pośrednictwa AK przedstawić swój punkt widzenia ${ }^{32}$. Cztery dni później na łamach „Szańca” zaatakowano AK (w tekście nazwano ja „sanacja”), a stronnictwa tworzące PPP określono tam jako „tzw. demokracja”. Autor stwierdził, że NSZ może jedynie zaakceptować współpracę „na warunkach oszczędzajacych prestige każdej z organizacji” "33. Główny organ wyrażający stanowisko Grupy „Szańca” postawił sprawę w sposób niemogacy pozostawiać wątpliwości: scalenia z AK nie będzie, można natomiast współdziałać przy zachowaniu całkowitej odrębności. 15 października - termin wyznaczony przez komendanta AK przywódcom TNRP-NSZ na rozpoczęcie scalenia nie został dotrzymany.

Dwa dni przed jego upływem wyruszył do Londynu Tadeusz Salski reprezentant części NSZ wywodzącej się z Grupy „Szańca” [Organizacja Polska (OP)-ONR], który 24 XII 1943 r. dotarł do sztabu Naczelnego Wodza. Natomiast delegat TNRP Stanisław Żochowski rozpoczął podróż 4 XI 1943 r., a w Londynie pojawił się 2 II 1944 r. Wysłanie niezależnie do siebie dwóch emisariuszy przez dwa różne środowiska było odbiciem głębokich podziałów w kierownictwie NSZ.

Salski przekazał szefowi sztabu Naczelnego Wodza gen. Sosnkowskiemu „Warunki podporządkowania się” NSZ komendantowi AK, których treść precyzyjnie oddaje, jak scalenie wyobrażali sobie liderzy NSZ wywodzący się z ONR ${ }^{34}$. W myśl pierwszych czterech punktów dokumentu NSZ otrzymałyby w praktyce całkowitą niezależność, a jedynym elementem łączącym je z AK byłaby osoba Dowódcy NSZ, któremu powierzono by stanowisko zastępcy komendanta AK „do spraw NSZ”. Komendant Główny AK, ani żaden inny dowódca AK, nie miałby prawa wydać członkom tak „scalonego” NSZ samodzielnie żadnego rozkazu, wszystkie musiałyby być przekazywane przez „zastępce AK do spraw NSZ”, czyli Dowódcę NSZ. To on miał decydować, jakie polecenia dotrą do jego podkomendnych, a jakie nie, czyli otrzymałby

\footnotetext{
${ }^{31}$ K. Komorowski, Polityka i walka..., s. 401-402.

32 Ibidem, s. 403.

${ }^{33}$ Drogi rozwoju NSZ, „Szaniec”, 6 X 1946, nr 13 (104).

${ }^{34}$ SPP, A 434, NSZ, Warunki podporządkowania się NSZ komendantowi AK dostarczone przez Tadeusza Salskiego, 10 I 1944 r., k. 3-4. Treść w załączniku.
} 
możliwość cenzurowania Komendanta Głównego AK. Jednocześnie w myśl pktu 2 mógłby on wydać podkomendnym z NSZ każdy rozkaz jako Komendant Sił Zbrojnych w Kraju, bez żadnych ograniczeń. W myśl pktu 3 sztab NSZ nie stałby się częścią KG AK, ale byłby równoległym, samodzielnym ośrodkiem dowodzenia, „współpracującym ściśle” w wybranych dziedzinach z dowództwem AK. Ową odrębność NSZ i ich równorzędność w stosunku do AK podkreśla dodatkowo pkt 14 dokumentu.

Punkty mówiące o odrębności terenowych siatek NSZ zastrzegały, iz oddziały NSZ niepodlegając komendantom PSZ sa jedynie „oddane do ich dyspozycji”. PSZ tworzone były jako struktura apolityczna, zhierarchizowana i oparta na posłuszeństwie. W tym kontekście zawarte w jednym z punktów żądanie, by to NSZ otrzymały wolna rękę do kontynuowania działań zbrojnych w Polsce „uwolnionej od okupantów”, gdyby postulaty polityczne tej organizacji nie zostały wcielone $\mathrm{w}$ życie, musiało wprawić w zdumienie nie tylko zawodowego wojskowego. NSZ domagał się bowiem carte blanche na zbrojną walkę z politycznymi przeciwnikami w okresie powojennym. Dokument zakładał, iż faktyczne scalenie nastapi dopiero po wojnie, ale i tu poczyniono zastrzeżenie, iż NSZ otrzymałyby prawo zablokowania włączenia swych oddziałów do WP, jeśli uznałoby, iż ich polityczne postulaty nie zostały spełnione ${ }^{35}$.

Szczególnie duże oczekiwania mieli przywódcy NSZ w kwestii stopni wojskowych. Nie dość, że oczekiwali pełnego, bezwarunkowego uznania wszystkich stopni wojskowych przyznanych przez NSZ i wcześniejsze współtworzące je organizacje, to jeszcze żądali czterokrotności awansów przyznanych przez AK. Zapewne uszczypliwy komentarz do przekazywanego Naczelnemu Wodzowi dokumentu stanowiło opatrzenie go uwaga, iż pismo dostarczył „niejaki Salski, podchorąży przed 1939 r., awansowany na porucznika NSZ"'36, co oznaczało, że w krótkim czasie „przeskoczył” trzy stopnie.

„Warunki podporządkowania się” były w kontrze do obowiązującej od powstania ZWZ filozofii budowania podziemnej armii w kraju, całego wcześniejszego rozkazodawstwa Naczelnego Wodza oraz praktyki scaleniowej wypracowanej i stosowanej przez KG ZWZ-AK wobec wcześniej scalonych organizacji.

Odpowiadajacy za łączność z krajem ppłk Michał Protasewicz w piśmie informującym szefa sztabu Naczelnego Wodza gen. Stanisława Kopańskiego o przybyciu Salskiego oceniał, że dotychczasowy brak podporządkowania NSZ dowództwu AK wynika przede wszystkim z „ambicji personalnych NSZ”. Napisał on: „Uważam za niewskazane by Naczelny Wódz wydał jakiekolwiek

${ }^{35}$ Zastrzeżenie to zawierał pkt 8 dokumentu, w którym czytamy: „Po usunięciu z kraju okupantów w wypadku, gdyby postulaty polityczne do tego czasu nie weszły w życie oddziały NSZ zachowują wolną rękę w wypełnianiu zadań, które stanowią ideowy cel ich istnienia”. Ibidem, k. 3.

${ }^{36}$ Ibidem, Naczelny Wódz gen. Sosnkowski do Komendanta Głównego AK gen. Komorowskiego, pismo wstępne do Warunków wstępnych podporządkowania się NSZ komendantowi AK dostarczonych przez Tadeusza Salskiego, 10 I 1944 r., k. 2. 
rozkazy dotyczące podporządkowania NSZ z pominięciem D[owód]-cy Armii Krajowej"'37. Zasugerował też, by z Salskim kontaktował się szef sztabu Naczelnego Wodza, a nie Naczelny Wódz. W rozmowie takiej, według Protasewicza, należało podkreślić, iż „Podporządkowanie NSZ Dowódcy Armii Krajowej [...] może być załatwione jedynie w Kraju przez D[owód]-cę Armii Krajowej”38.

10 stycznia gen. Sosnkowski dostarczony przez Salskiego dokument przesłał do wiadomości gen. Komorowskiego. W piśmie wstępnym Naczelny Wódz podkreślił: „W zasadzie kwestię scalenia NSZ z AK uważam za ważną i pilna. Nie wydam jednak decyzji przed poznaniem opinii Pana Generała"39. Dwa dni później do Londynu dotarła depesza gen. Komorowskiego, wysłana z kraju 30 XII 1943 r. Komorowski przypomniał w niej, że NSZ nie wykonały rozkazu Wodza Naczelnego z 3 XI 1942 r. oraz rozkazu dowódcy AK z 9 XI 1943 r. nakazującego scalenie z AK, i apelował o niedopuszczenie kpt. Żochowskiego ${ }^{40}$ do Wodza Naczelnego, gdyż kontakty na takim szczeblu „,szłyby na rękę NSZ, których stanowisko jest warcholskie i naruszałoby autorytet dowódcy Armii Krajowej”. Prosił też o nakazanie Żochowskiemu natychmiastowego powrotu i „zameldowanie się u mnie do służby”"

Wódz Naczelny gen. Sosnkowski, wbrew sugestiom ppłk. Protasewicza i gen. Komorowskiego, zdecydował się przyjać przedstawicieli NSZ. Być może chciał poznać opinię o sytuacji w podziemiu z ust ludzi krytycznie nastawionych do AK, a może wpływ na jego decyzję miały listy polecające od płk. Kurcyusza, jakie przywieźli ze sobą Salski i kpt. Żochowski. W jednym z nich, adresowanym do szefa sztabu Naczelnego Wodza gen. Kopańskiego, Dowódca NSZ obwiniał o fiasko rozmów scaleniowych obecna jakoby w sztabie AK „grupę ludzi pracujących dla rządu przedwojennego". List zakończył apelem: „Zachodzi konieczność uregulowania tych spraw przez rozkaz Nacz[elnego] Wodza. Jestem zdania, że w kraju brak jest na stanowiska kierownicze w Armii Krajowej odpowiednich kandydatów z należytym autorytetem i nie obarczonych przynależnością do obozu znienawidzonego w kraju. Przesłanie ich z Anglii jest koniecznościa" 42 . Dowódca NSZ negował więc prawo dowództwa AK do kierowania walka podziemną w kraju i oczekiwał od władz Rzeczypospolitej ich odwołania i zastapienia ludźmi przysłanymi z Londynu.

${ }^{37}$ Ibidem, Pismo ppłk. Michała Protasewicza do szefa Sztabu Naczelnego Wodza z 29 XII 1943, k. 51.

${ }^{38}$ Ibidem.

${ }^{39}$ Ibidem.

${ }^{40}$ W tym czasie kpt. Żochowski był jeszcze w drodze (trasa Węgry-Turcja-Środkowy WschódWielka Brytania), do Londynu dotarł 4 II 1944 r., a Naczelny Wódz udzielił mu audiencji 14 II $1944 \mathrm{r}$.

${ }^{41}$ SPP, A 434, NSZ, Ppłk Michał Protasewicz do Naczelnego Wodza. Treść depeszy gen. Komorowskiego z 30 XII 1943 r. otrzymanej z Kraju w dniu 12 I 1944 r., k. 53.

${ }^{42}$ Do Szefa Sztabu Naczelnego Wodza WP Generała Kopańskiego w Anglii, sygnował Morski, ppłk dypl. D-ca NSZ, Warszawa 1 X 43 r., zob. Z.S. Siemaszko, op. cit., s. 120. 
Dokument ten pokazuje głęboką niechęć płk. Kurcyusza do oficerów KG AK, których uważał za emanację sanacji. W tym względzie jego stanowisko pokrywało się z poglądami prezentowanymi przez przywódców Grupy „Szańca”. Odróżniała go jednak od nich lojalność wobec Wodza Naczelnego i rządu w Londynie. Kurcyusz zakładał zapewne, że władze na uchodźstwie sa źle poinformowane odnośnie do sytuacji w kraju, co rzutuje na ich stosunek do NSZ. Siemaszko zauważył, że płk Kurcyusz był kilkanaście lat starszy od czołowych przywódców AK i przed wojną w strukturze armii zajmował wyższe od nich stanowisko. Starszy oficer, zmuszony do podporządkowania się dowódcy jeszcze niedawno stojącemu niżej w wojskowej hierarchii, znalazł się w trudnej psychologicznie sytuacji. Według Siemaszki różnica pokoleniowa, urażona duma i przywódcze ambicje prawdopodobnie wzmacniały głęboka niechęć, jaką Dowódca NSZ żywił do $\mathrm{AK}^{43}$.

13 I 1944 r. gen. Sosnkowski przyjał Salskiego, a 17 stycznia wysłał do dowódcy AK depeszę, do której załączył projekt umowy scaleniowej, zatytułowany „Wytyczne włączenia NSZ do AK”. Domagał się od komendanta AK odniesienia się „do projektu i w razie braku zastrzeżeń zaakceptowanie, oraz podanie do wiadomości $\mathrm{D}$ [owód]cy NSZ w tej sprawie jako moich wytycznych. Intencja moja jest zachowanie w ramach AK całkowitego dorobku tej organizacji dla walki z wrogiem”. Na koniec Sosnkowski podkreślił: „Od początku istnienia NSZ trzymałem się niezmiennie zasady zjednoczenia ruchu zbrojnego pod jednolitym dowództwem i kierownictwem władz legalnych" ${ }^{44}$. Była to więc propozycja, a nie rozkaz. Ostateczną decyzję winien podjąć gen. Komorowski. W myśl „Wytycznych” Naczelnego Wodza sztab NSZ miał zostać „włączony do Sztabu AK, z utrzymaniem takiej odrębności, jaka jest konieczna dla zapewnienia rozwoju konspiracji”, struktura terytorialna NSZ „dopasowana” do siatki terytorialnej AK. Oddziały wojskowe do kompanii, zaś w wyjątkowych wypadkach batalionu, zachowywały dotychczasowy skład i profil, natomiast jednostki od batalionu w górę miały posiadać całkowicie AK-owski, niepolityczny charakter. Dokument zakładał też konieczność weryfikacji wszelkich stopni i odznaczeń NSZ przez komisje $\mathrm{AK}^{45}$.

Historycy zajmujacy się dziejami NSZ odmiennie oceniaja efekty misji Salskiego. Według Wojciecha J. Muszyńskiego „gen. Sosnkowski w sprawie scalenia NSZ staną właściwie po stronie NSZ” ${ }^{46}$. Krzysztof Komorowski

\footnotetext{
${ }^{43}$ Z.S. Siemaszko, op. cit., s. 61-63.

${ }^{44}$ SPP, A 434, NSZ, Depesza Naczelnego Wodza gen. Sosnkowskiego do komendanta głównego AK gen. Komorowskiego stanowiąca wstęp do Projektu Sztabu Naczelnego, Wytyczne włączenia NSZ do AK, 20, k. 9.

${ }^{45}$ Ibidem, Projekt Sztabu Naczelnego, Wytyczne włączenia NSZ do AK, k. 10.

${ }^{46}$ Ocena ta wynika z omyłkowego uznania przez Muszyńskiego opracowanych przez NSZ „Warunków podporządkowania się” za stanowisko Naczelnego Wodza, przy jednoczesnym pominięciu dokumentu, który rzeczywiście pełnił taką rolę, jakim był „Projekt Sztabu Naczelnego, Wytyczne włączenia NSZ do AK”. Zob. W.J. Muszyński, op. cit., s. 304.
} 
zauważył natomiast, że rozmowa z emisariuszem NSZ nie pociagnęła za sobą poważniejszego zaangażowania Naczelnego Wodza w sprawę ${ }^{47}$. Z kolei Siemaszko uznał, że Salski odegrał trzecioplanową rolę, i odrzucił hipotezę, jakoby miał on jakikolwiek wpływ na podejmowane przez Naczelnego Wodza decyzje. Rozważania swe zakończył następującym wnioskiem: „delegaci NSZ w Londynie niczego właściwie nie osiagnęli” ${ }^{2}$. Analiza „Wytycznych” Naczelnego Wodza każe przyznać rację Siemaszce.

Szef Oddziału Specjalnego ppłk Protasewicz starał się wpłynąc na gen. Sosnkowskiego, argumentując, iż „Wytyczne włączenia NSZ do AK” skomplikuja położenie komendanta AK i moga zostać wykorzystane do podważenia jego autorytetu $^{49}$. Nie przekonał jednak Naczelnego Wodza i dokument został wysłany do okupowanego kraju.

W odpowiedzi komendant AK podkreślił, że docenia wagę scalenia NSZ z AK, po czym podkreślił, że udzielenie NSZ ,jakichkolwiek dalej idących uprawnień niż wszystkie inne organizacje wywołałby zamęt i mogłoby doprowadzić do rozbicia, a co najmniej do poważnego fermentu wśród scalonych już organizacji i narazić na szwank z takim trudem przeprowadzone cementowanie Armii Krajowej. [...] Proszę, by Pan Generał pozostawił nadal w mych rękach decyzję w sprawie scalenia, a zaapelował do NSZ depeszą skierowana na moje ręce, by dla dobra ogólnego sprawy nie przeciagali i porządkowali się na określonych przeze mnie zasadach. Taka depesza ułatwi mi znacznie dociśnięcie ich do podporządkowania się i byłaby na czasie"50.

Generał Komorowski zdecydował, że nie przekaże TNRP dziewięciopunktowych „Wytycznych...”, choć nie faworyzowały one NSZ względem innych, scalonych wcześniej organizacji. Dowódca AK nie chciał zapewne stwarzać precedensu w postaci włączania Naczelnego Wodza w proces podporządkowywania sobie kolejnych organizacji zbrojnych. Scalenie w oparciu o przysłane z Londynu wytyczne otwierałoby liderom NSZ drogę do odwoływania się do Naczelnego Wodza od każdej decyzji dowódcy AK, z którą oni by się nie zgadzali. Przed taką właśnie sytuacją przestrzegał ppłk Protasewicz, pisząc, iż wkroczenie gen. Sosnkowskiego w kompetencje zarezerwowane dotychczas dla dowódcy ZWZ-AK „podważałoby to autorytet Komendanta Sił Zbrojnych w Kraju”.

W Warszawie na przełomie grudnia i stycznia wznowione zostały zerwane w październiku 1943 r. rozmowy AK-NSZ. Tymczasem posuwające się za wycofującymi się wojskami niemieckimi jednostki Armii Czerwonej wkroczyły na ziemie wschodnie II RP. Dla negocjujących stron było jasne, że to już ostatni moment na podpisanie ustaleń i skuteczne przeprowadzenie

${ }^{47}$ Ibidem.

${ }^{48}$ Z.S. Siemaszko, op. cit., s. 120.

${ }^{49}$ Ibidem.

${ }^{50}$ SPP, A 434, NSZ, Depesza komendanta głównego AK gen. Komorowskiego do Naczelnego Wodza gen. Sosnkowskiego z 3 II 1944 r. odebrana w Londynie 18 lutego i odszyfrowana 19 lutego, k. 11. 
scalenia. Przewodniczący TNRP Stypułkowski tym razem zdecydowanie parł do podpisania umowy. 26 I i 8 II 1944 r. prezydium TNRP i przedstawiciele dowództwa AK wypracowali zasady włączenia NSZ do $\mathrm{AK}^{51}$. Za scaleniem opowiedzieli się działacze wywodzący się z ONR-OP i większość frondystów z SN. Sprzeciw zgłosił członek prezydium TNRP Karol Stojanowski. Poparło go kilku frondystów, w tym Władysław Pacholczyk z KG NSZ. Byli oni zwolennikami stworzenia, w oparciu o NOW-AK i NSZ, odrębnej Armii Narodowej zrzeszającej wszystkie ugrupowania o profilu narodowym. Nie zdołali oni jednak przekonać do swej koncepcji liderów narodowego podziemia.

Uzgodniona umowa scaleniowa zawierała najważniejsze elementy „Projektu umowy”, przekazanej 15 IX 1943 r. negocjatorom TNRP-NSZ i przez nich odrzuconej, oraz dziewięciopunktowych „Wytycznych włączenia NSZ do AK” Naczelnego Wodza. W myśl tego dokumentu Dowódca NSZ miał najpierw zostać przedstawiony Komendantowi Sił Zbrojnych w Kraju, po czym ten odbierał od Dowódcy NSZ przysięgę AK i mianował go pełnomocnikiem do spraw NSZ. „Niezwłocznie” po tej uroczystości powinno się rozpocząć scalenie na wszystkich szczeblach organizacji. Umowa zakładała, że dowództwa terenowe NSZ zostaja zachowane jako „komendy zbiorczo-organizacyjne” z prawem prowadzenia działań propagandowych. Oddziały liniowe do szczebla batalionu działać będą w niezmienionym składzie i zachowają dotychczasowe nazwy. Stopnie wojskowe, odznaczenia i patenty podlegały weryfikacji przez komisje AK, z dniem scalenia zaś członkowie NSZ otrzymywali „wszystkie prawa żołnierzy przyznane przez Rząd Rzeczypospolitej i Naczelnego Wodza dla AK". Porozumienie przewidywało też wydanie rozkazów lub komunikatów inforumujących o scaleniu tak przez Komendanta Sił Zbrojnych, jak Dowódcę NSZ i opublikowanie ich $\mathrm{w}$ prasie podziemnej, przy czym zastrzegano, że „Teksty tychże, data i sposób ogłoszenia będą uzgodnione przez obie strony” ${ }^{2}$.

Przed podjęciem przez TNRP decyzji o podpisaniu umowy przewodniczący Stypułkowski otrzymał informację, iż gen. Komorowski wie, kto jest Dowódca NSZ i nie wyraża zgody, by obciążany poważnymi zarzutami płk Kurcyusz został jego pełnomocnikiem do spraw NSZ. Według gen. Komorowskiego Stypułkowski „uznając zastrzeżenia Dowódcy AK prosił, aby na zebraniu w dniu 7 III br. oficjalnie sprawy tej nie poruszać a w ciagu 7 dni przedstawi on rezygnacje płk. «Żegoty» [płk. Tadeusza Kurcyusza] ze stanowiska Dowódcy NSZ i zgłosi osobę nowego Dowódcy"53. Generał Komorowski zaakceptował propozycję.

$\mathrm{Na}$ atmosferę negocjacji miała wpływ depesza Naczelnego Wodza z 24 II 1944 r. W przesłanym do gen. Komorowskiego, a zaadresowanym

\footnotetext{
51 Ze strony TNRP-NSZ dokumenty negocjacyjne podpisali Zbigniew Stypułkowski „Czemp” i Jan Matłachowski „Ostoja”, ze strony AK - gen. Tadeusz Komorowski.

${ }^{52}$ Umowa scaleniowa Sił Zbrojnych i Armii Krajowej, 7 III 1944 r., w: Z.S. Siemaszko, op. cit., s. 234-235.

${ }^{53}$ SPP, A 434, NSZ, Załącznik do pisma do Pełnomocnika Rządu w Kraju z dn. 5 VII 1944 r.
} 
„Dla Komendanta NSZ” liście gen. Sosnkowski pisał o konieczności „zjednoczenia wysiłków wszystkich uczciwych Polaków dla odzyskania niepodległości Rzeczypospolitej Polskiej” i polecał Dowódcy NSZ możliwie najszybsze podporządkowanie kierowanej przez niego organizacji komendantowi AK. W ostatnim zdaniu podkreślił, iż NSZ nie mogą liczyć na otrzymanie „dalej idących uprawnień niż [przyznane] wszystkim innym organizacjom, gdyż tego rodzaju polityka przywileju wywołać by mogła zamęt i szkodliwy ferment wśród organizacji już scalonych" ${ }^{24}$. List pokazal, że emisariusze NSZ nie przekonali Naczelnego Wodza i oczekiwał on scalenia NSZ na warunkach podobnych do tych, na jakich wchodziły do ZWZ-AK inne organizacje podziemne. Przywódcy NSZ z jednej strony mogli się czuć zaszczyceni otrzymaniem listu od dowódcy PSZ, z drugiej zaś nie powinni już twierdzić, że żądania dowództwa AK stoja w sprzeczności z wytycznymi Naczelnego Wodza.

7 III 1944 r. delegacja TNRP-NSZ, w składzie Stypułkowski, Marcinkowski, Jan Matłachowski, doręczyła komendantowi AK uchwałę TNRP podporządkowująca NSZ dowództwu AK. Przedstawiciele TNRP-NSZ i gen. Komorowski podpisali „Ważniejsze zasady przeprowadzenia scalenia Narodowych Sił Zbrojnych z Armia Krajowa" "55, po czym strony uzgodniły skład wspólnej komisji technicznej, której członkowie mieli się zająć wcielaniem w życie postanowień umowy ${ }^{56}$. Tym samym przygotowane zostały wszystkie niezbędne procedury. By proces scalenia ruszył z miejsca, potrzebne było jedynie zaprzysiężenie Dowódcy NSZ przez Komendanta Sił Zbrojnych w Kraju. I tu właśnie pojawił się problem.

W połowie marca upłyną termin rezygnacji płk. Kurcyusza, ten jednak dymisji nie złożył, TNRP nie zgłosiła też innego kandydata na pełnomocnika do spraw NSZ. Mimo to 15 marca gen. Komorowski ogłosił rozkaz, iż w związku z podporządkowaniem się dowództwa NSZ Komendzie Sił Zbrojnych w Kraju przestaje obowiązywać jego rozkaz z listopada 1943 r. (nr 122), w myśl którego członkostwo w NSZ nie było uznawane za służbę w siłach zbrojnych $\mathrm{RP}^{57}$. Tego samego dnia wysłał do Naczelnego Wodza depeszę, w której przewidywał:

Przyjęcie NSZ do SZ w Kraju spowoduje przeciwko nam akcję propagandową PPR i ugrupowań lewicy polskiej. Zdecydowałem rozpoczęcie rozmów na temat podporządkowania PAL [Polska Armia Ludowa]. PAL jest aktywem paramilitarnym RPPS [Robotnicza Polska Partia Socjalistyczna], o ograniczonym zasięgu terenowym

${ }^{54}$ Ibidem, Depesza: Dnia 24 II 1944, Lawina/Dla Komendanta NSZ, sygnowana Wódz Naczelny Sosnkowski gen. Broni, k. 16.

55 Ważniejsze zasady przeprowadzenia scalenia Narodowych Sił Zbrojnych z Armia Krajowa, aneks w: K. Komorowski, Polityka i walka..., s. nlb.

${ }^{56}$ SPP, A 434, NSZ, Załącznik do pisma do Pełnomocnika Rządu w Kraju z dn. 5 VII 1944 r.

57 Ibidem, Zniesienie rygorów nałożonych na członków NSZ rozkazem nr 122, gen. Komorowski do komendantów obszarów i okręgów AK, pismo Nr 14/I/NSZ, 15 III 1944, k. 60. 
i szczupłej liczbie. [...] odepchnięcie PAL wepchnęłoby go w ramy PPR [...] scalenie PAL-u jednoczy cały obóz niepodległościowy na płaszczyźnie wojskowej. Wówczas, poza zjednoczonymi SZ w Kraju pozostaną wyraźnie odosobnione obce agentury ${ }^{58}$.

Dokument oddaje istotny dla AK niewojskowy, polityczny cel scalenia. Pokazuje również fundamentalną różnicę myślenia między dużą częścią przywódców NSZ a kierownictwem PPP i AK. Pierwsi uważali, że komunistów należy zabijać, drudzy zaś chcieli ich izolować. W ocenie dowództwa AK wystapienie zbrojne przeciwko komunistom prowadzić musiało do walk bratobójczych i dostarczałoby Józefowi Stalinowi argumentów przeciwko rzadowi na uchodźstwie, i tym samym osłabiało jego pozycję wobec zachodnich aliantów.

Tymczasem tarcia $\mathrm{w}$ łonie TNRP i sztabie NSZ nie ustawały, wręcz przeciwnie - nasiliły się. Liderzy Grupy „Szańca” nakłaniali płk. Kurcyusza do nieustępliwości. Bliski ich środowisku por. Leonard Zub-Zdanowicz „Zab” ${ }^{59}$ w powstałym po wojnie opracowaniu napisał: „AK żąda ustapienia płk. Kurcyusza, nie ma żadnych zarzutów - po prostu jest im politycznie niewygodny, słusznie przewidujacc, że może nadejść dzień, że płk Kurcyusz, jako najpoważniejszy oficer na terenie Kraju, może zostać przez Londyn wyznaczony dowódca wszystkich Sił Zbrojnych w Kraju. A do tego sanacja dopuścić nie może"60. Późniejszy szef sztabu Brygady Świętokrzyskiej ignorował poważne zarzuty wobec płk. Kurcyusza i sugerował, iż obiekcje gen. Komorowskiego wynikały ze strachu o własne stanowisko. ONR-owskie otoczenie Dowódcy NSZ utrzymywało go w przekonaniu, iż jest najodpowiedniejszym kandydatem na przywódcę podziemia w kraju i jednocześnie podsycało jego antyakowskie uprzedzenia. W tym samym czasie stronnicy Stypułkowskiego domagali się jego szybkiego ustapienia, na to nakładała się inicjatywa Stojanowskiego utworzenia Armii Narodowej. W tej sytuacji gen. Komorowski zażądał, by komisja techniczna rozpoczęła pracę, pomimo że Dowódca NSZ nie został zaprzysiężony przez Komendanta Sił Zbrojnych w Kraju. Pracujące w niepełnym składzie gremium przygotowało projekt rozkazu scaleniowego.

31 III 1944 r. u dowódcy AK stawili się wysłannicy TNRP-NSZ - Stypułkowski i Marcinkowski. Zwrócili się do gen. Komorowskiego z prośba o przyjęcie płk. Kurcyusza w charakterze Dowódcy NSZ. Gest ten miałby mu pozwolić na honorowe zrzeczenie się dowództwa po dwóch tygodniach. Scalenie winien przeprowadzić już nowy dowódca ${ }^{61}$. Odnosząc się bezpośrednio do tego wydarzenia, reprezentujący środowisko Grupy „Szańca” Iłłakowicz napisał:

\footnotetext{
${ }^{58}$ Ibidem, Gen. Komorowski do gen Sosnkowskiego, depesza z 15 III 44 r. odebrana w Londynie 27 III 1944 r., k. 64.

${ }^{59}$ Por. Leonard Zub-Zdanowicz w NSZ najpierw używał stopnia rotmistrza (odpowiednik kapitana kawalerii), a następnie podpułkownika.

${ }^{60}$ SPP, A 434, NSZ, L. Zub-Zdanowicz, Narodowe Siły Zbrojne, mps, k. 165.

${ }^{61}$ Ibidem, Załącznik do pisma do Pełnomocnika Rządu w Kraju z dn. 5 VII 1944 r.
} 
Istniała bardzo silna presja dołów NSZ w kierunku scalenia z AK i mimo naszych wysiłków musieliśmy się zgodzić na niekorzystne warunki scaleniowe oraz upokarzająca nieobecność D[owód]-cy NSZ przy akcie podpisania scalenia. Wymogliśmy jednak, że Kurcyusz zostanie przez Bora zaprzysiężony jako dowódca NSZ. To zgodnie z relacja Marcinkowskiego - było bardzo trudne do przeprowadzenia i na to Bór po paru godzinach dyskusji wreszcie się zgodził ${ }^{62}$.

Charakterystyczne, iż Iłłakowicz pominął w swej relacji fakt zobowiązania się płk. Kurcyusza do rezygnacji z funkcji, co miało nastapić w połowie kwietnia.

Natychmiast po spotkaniu przedstawiciele TNRP-NSZ sprowadzili na miejsce spotkania Dowódcę NSZ. Ten przyją wypracowane ustalenia i stwierdził, „że z powodu choroby nie może pełnić obowiązków D[owód]-cy NSZ. Jako swego zastępcę i następcę wskazał ob. Tuwara [ppłk Wacław Świeciński] szefa sztabu NSZ" ${ }^{63}$. Sukcesja taka byłaby zgodna z regulaminem NSZ ${ }^{64}$. Tego samego dnia płk Kurcyusz i gen. Komorowski wydali odpowiednie rozkazy. Dowódca NSZ ogłosił podporządkowanie podległych mu sił Komendantowi Sił Zbrojnych w Kraju, stwierdził, że NSZ nie pozwoli na wykorzystanie ofiary swych członków „dla małych celów partyjno-politycznych” i zapowiedział walkę o „Polskę niewzruszoną w granicach wschodnich, a rozszerzona o Odrę i Nysę Łużycką" ${ }^{65}$. Generał Komorowski zaś zwracał się do członków NSZ następującymi słowami:

Witam Was w szeregach Armii Krajowej. Mam głębokie przeświadczenie, że Oddziały Narodowych Sił Zbrojnych wnoszą do zjednoczonego wysiłku Kraju wartościowy wkład obywatelski i żołnierski. Uzyskując obecnie pełne uprawnienia, przysługujące wszystkim dobrym żołnierzom Armii Krajowej, wnieście w Jej szeregi swój entuzjazm i wiarę w Wielkość Sprawy. Swą karnościa, zdyscyplinowaniem, wyszkoleniem żołnierskim i obywatelskim, a przede wszystkim gotowością do ofiar sięgnijcie po najwyższą nagrodę - Wolność i Wielkość Ojczyzny!66

Z optymistycznym tonem rozkazu scaleniowego kontrastuje opinia dowódcy AK zawarta w depeszy do Naczelnego Wodza:

Kierownictwo NSZ ma na swoim sumieniu nielojalne i kłamliwe chwyty, których używało w ciagu jednego i pół roku podczas rozmów scaleniowych, by uzyskać dla

${ }^{62}$ J.O. Iłłakowicz, O Narodowych Siłach Zbrojnych, „Zeszyty Historyczne” 1986, z. 76, s. 96. Tekst ten składa się z krótkiego wstępu autorstwa Z.S. Siemaszki oraz listu J.O. Iłłakowicza do Z.S. Siemaszki, 30 IV 1982.

${ }^{63}$ SPP, A 434, NSZ, Załącznik do pisma do Pełnomocnika Rządu w Kraju z dn. 5 VII 1944 r.

${ }^{64}$ Ibidem, Zasady organizacji i funkcjonowania Dowództwa NSZ, 16 XI 1943, L. 54/43, k. 98. Regulamin przewidywał: „W razie chwilowej nieobecności Dcy NSZ zastępuje go Zastępca Szefa Sztabu - osobiście i w oparciu o szefów wydziałów I, II, III i VI oraz Szefa Służby Łączności”. Ibidem.

${ }^{65}$ Rozkaz dowódcy NSZ opublikowany w: „Szaniec”, 15 IV 1944, nr 3.

${ }^{66}$ Rozkaz dowódcy AK opublikowany w: „Biuletyn Informacyjny”, 13 IV 1944, nr 15. 
swej organizacji specjalne warunki i przywileje w ramach SZ w Kraju. W tej akcji wybitna rolę grały względy prestiżowe i ambicjonalne oraz celowe uderzenie w autorytet Armii Krajowej. [...] Liczę się z tym, że przy praktycznym realizowaniu scalania NSZ napotkam na poważne trudności z ich strony, które będę musiał spokojnie, ale stanowczo usuwać z myślą o oddziaływaniu wychowawczym zmierzającym do podniesienia dyscypliny [...] NSZ sa jedyną bodaj w Kraju grupa o zabarwieniu totalistycznym ${ }^{67}$.

Obawy gen. Komorowskiego szybko się potwierdziły. 15 kwietnia, dzień po upłynięciu terminu, w którym płk Kurcyusz powinien podać się do dymisji, wydał rozkaz w sprawie scalenia. Przemianowywał w nim „Dowództwo NSZ” na „Komendę Główną NSZ” i wprowadzał nazwę „Komendy Okręgowe NSZ", co było dostosowaniem nazewnictwa do nomenklatury obowiazującej w AK. Informował też członków NSZ, że „z dniem aktu scalenia /31.III.44r./ otrzymali wszystkie prawa żołnierzy przyznane przez Rząd Rzeczypospolitej i Naczelnego Wodza dla AK”. W myśl ostatniego punktu dokumentu „właściwa akcja scaleniowa” powinna się rozpocząć w nieokreślonej jeszcze przyszłości, o czym miał poinformować osobny rozkaz wykonawczy wydany przez komendanta AK i komendanta NSZ ${ }^{68}$. Kurcyusz z jednej strony przyznawał swym podkomendnym wszystkie prawa wynikajace ze służby w AK, z drugiej zamrażał proces scalenia, a jego odmrożenie uzależniał od przyszłych, niedookreślonych uzgodnień. Dokument ten dobrze odzwierciedla dylemat dowódcy, który starał się osiagnać kolidujące ze sobą cele. Chciał mianowicie, by jego formacja stała się częścią jednolitego z definicji WP, a jednocześnie próbował zagwarantować komendantowi NSZ decydujący wpływ na tempo i głębokość scalenia.

Tymczasem w łonie TNRP narastały napięcia. W wyniku scalenia frondyści z SN powrócili do rodzimej partii i weszli do instytucji PPP. Według Muszyńskiego niedawni partnerzy współtworzący NSZ z SN teraz opowiedzieli się przeciwko włączaniu działaczy OP-ONR do struktur politycznych PPP, „gdyż nie zamierzali się dzielić swoją władza”. Historyk dodał: „Członkowie kierownictwa podziemnego środowiska OP-ONR zrozumieli, że taki rozwój wypadków doprowadzi do odebrania im przez AK pionu wojskowego, który po scaleniu nie będzie mógł być używany jako argument w rozgrywce politycznej”69. Trafnie zdiagnozował on, że w myśleniu radykalnych narodowców posiadanie własnej formacji zbrojnej służyło w pierwszym rzędzie osiaganiu bieżących celów polityczno-partyjnych, co było fundamentalnie sprzeczne z założeniami, na jakich opierała się AK. Tłumaczy to też, dlaczego oenerowcy

${ }^{67}$ SPP, A 434, NSZ, Gen. Komorowski do gen Sosnkowskiego, depesza z 15 III 44 r. odebrana w Londynie 27 III 1944 r., k. 64.

${ }^{68}$ K. Komorowski, Polityka i walka..., s. 421. Autor ten powołuje się na „Rozkaz wstępny do akcji scaleniowej NSZ w ramach AK" z 15 IV 1944 r. oraz uzupełniające go osiem załaczników. Dokumenty te zostały opatrzone opisem „kopia w zbiorach autora”.

${ }^{69}$ W.J. Muszyński, op. cit., s. 310. 
zaczęli przekonywać płk. Kurcyusza do nieustępowania ze stanowiska, w terenie zaś rozniecili kampanię przeciwko scaleniu. Sposób myślenia i nastroje tego środowiska oddaja wspomnienia Tadeusza Mazura:

\begin{abstract}
Do scalenia parła głównie grupa Stypułkowskiego. Część dawnego ZJ [Związku Jaszczurczego] szła też w tym kierunku, ale bez zbytniego entuzjazmu. Zwłaszcza średniego kalibru działacze z przedwojennego środowiska akademickiego, z rezerwa patrzyli na rozwój wypadków. Nasza grupka od początku odnosiła się do scalenia wprost z niechęcią. [...] Cały sens powstania i istnienia odrębnej organizacji wojskowej, leżał w tym, że uważaliśmy, że oficjalna polityka polska nie jest niezależna, jest pod stałym naciskiem obcym i jest do tego jeszcze infiltrowana przez wrogów narodu polskiego. W sumie, że nie reprezentuje polskiej racji stanu. Wprost przeciwnie, działa na niekorzyść naszego narodu ${ }^{70}$.
\end{abstract}

W opinii autora powyższych słów poważna grupa działaczy OP-ONR uważała, że rząd polski na uchodźstwie, PPP i prezydent RP prowadzili działalność niezgodna z interesami państwa i narodu polskiego.

W połowie kwietnia upłynęło pięć tygodni od podjęcia przez TNRP uchwały podporządkowującej NSZ Komendantowi Sił Zbrojnych w Kraju, a wciąż nie rozpoczą się proces scalania, nie wyznaczono nawet pełnomocnika do spraw scalenia. Generał Komorowski nalegał na Stypułkowskiego, by kierowana przez niego TNRP wypełniła zobowiązanie, jakim było wyznaczenie kandydata na nowego pełnomocnika do spraw NSZ. Stypułkowski i szef Wydziału Wojskowego TNRP Michałowski spotkali się z płk. Kurcyuszem i bezskutecznie domagali się, by ten zgodnie z obietnica złożył dowodzenie. 20 kwietnia z Dowódca NSZ odbył rozmowę wyznaczony na jego następcę szef sztabu NSZ ppłk Wacław Świeciński „Tuwar”" Także i podczas tego spotkania nie doszło do ostatecznych rozstrzygnięć.

Następnego dnia trzech członków prezydium TNRP z Grupy „Szańca”: Wawrzkowicz, Iłłakowicz, Stanisław Kasznica i reprezentujący to samo środowisko kierownik Służby Cywilnej Narodu (SCN) ${ }^{72}$ Kazimierz Gluziński spotkali się z płk. Kurcyuszem. ONR-owcy zdecydowali, że powrót frondystów do SN unieważnia mandat TNRP, w związku z czym uznali organ ten za rozwiązany i w to miejsce utworzyli Radę Polityczną przy Dowództwie NSZ. Znaleźli się w niej wyłącznie przedstawiciele Grupy „Szańca”. Zebrani nakłonili dowódcę NSZ, by pozostał na stanowisku. Według Krzysztofa Komorowskiego w trakcie spotkania ONR-owcy prawdopodobnie podzielili się z płk. Kurcyuszem planami dokonania zamachu stanu, polegającego na wystapieniu przeciwko przywódcom PPP, zastapieniu Delegatury Rządu na Kraj kontrolowaną przez Gluzińskiego SCN i powołaniu własnego konspiracyjnego rządu. Działania takie

${ }^{70}$ Cyt. za: Z.S. Siemaszko, op. cit., s. 125-126.

${ }^{71}$ Ppłk Wacław Świeciński w NSZ używał stopnia pułkownika.

${ }^{72}$ Podległa TNRP Służba Cywilna Narodu została stworzona jako konkurencyjna wobec Delegatury Rządu na Kraj podziemna, nacjonalistyczna administracja. 
byłyby rzecz jasna równoznaczne z podważeniem mandatu polskiego rządu na uchodźstwie. Na rzecz hipotezy o przygotowywanym zamachu przemawia relacja Stypułkowskiego, według którego jakiś czas po podpisaniu umowy scaleniowej odwiedzili go Wawrzkowicz, Marcinkowski i Iłłakowicz. Mieli oni stwierdzić, że wcześniej nie posiadali mandatu wynikającego z uczestnictwa w instytucjach państwa. Teraz, gdy scalenie doprowadziło do legalizacji oenerowców, powinni przechwycić władzę i utworzyć rząd ze Stypułkowskim na czele. Liderzy Grupy „Szańca” postawić mieli ultimatum - szefowanie rządowi w zamian za poparcie albo przewodniczący TNRP będzie przez nich zwalczany. Według Stypułkowskiego odrzucenie przez niego oferty stało się bezpośrednia przyczyna rozłamu w $\mathrm{NSZ}^{73}$.

Wersję Stypułkowskiego podważył Iłłakowicz, pisząc, iż to „zwykły szkalujaccy wymysł. Według niego Stypułkowski byłby ostatnią osoba, z która na tego rodzaju konspirację poszlibyśmy. Może moglibyśmy rozmawiać z [Augustem] Michałowskim, [Ludwikiem] Jaxą Bykowskim, może [Janem] Matłachowskim, ale nigdy Stypułkowskim". Iłłakowicz wymienił nawet nazwiska osób na tyle godnych zaufania, by stać się „twarza” takich działań. Jego argumentacja szła w kierunku podważenia wiarygodności osoby Stypułkowskiego. Posunął się do sugestii, iż został on zwerbowany przez NKWD i być może odgrywał rolę podobną do Bolesława Piaseckiego ${ }^{74}$.

Mamy więc złożone wiele lat po wojnie, wykluczające się relacje dwóch kluczowych, nieprzyjaznych sobie uczestników wydarzeń. Stypułkowski oskarżył liderów Grupy „Szańca” - w tym Iłłakowicza - o przygotowywanie w podziemiu zbrojnego przewrotu, na co Iłłakowicz odpowiedział próba podważenia wiarygodności oponenta, uciekając się do sugestii, iż słowa Stypułkowskiego wynikać moga z jego agenturalnego uwikłania. Nie przesądzając, czy propozycja wobec przewodniczącego TNRP faktycznie padła, to późniejsze wydarzenia pokazały, iż pomysł przechwycenia przez oenerowców władzy nad polskim podziemiem nie był wyłącznie wytworem wyobraźni Stypułkowskiego.

Wróćmy do spotkania liderów Grupy „Szańca” z dowódcą NSZ. Według oficera Sztabu Głównego NSZ, mjr. Tadeusza Danielewicza, spotkanie „było bardzo burzliwe, wywierające presję na płk. Kurcyusza, ażeby ze stanowiska komendanta NSZ nie ustępował. Płk Kurcyusz oświadczył, że swego stanowiska nie zmieni i opuścił zebranie w stanie wielkiego podniecenia, a będąc chorym na serce, po przybyciu do domu, nagle zmarł"75. Podsumowując, płk Kurcyusz zapowiedział złożenie dymisji, odmówił udziału w realizacji planów oenerowców (choć nie mamy pewności, jakie informacje mu przekazano), skrajnie wzburzony wyszedł ze spotkania i po dotarciu do domu doznał zawału serca.

\footnotetext{
${ }^{73}$ Z.S. Siemaszko, op. cit., s. 127.

74 J.O. Iłłakowicz, op. cit., s. 106-107.

${ }^{75}$ Cyt. za: Z. Siemaszko, op. cit., s. 126.
} 
Postępujący rozłam w NSZ uważnie obserwował Komendant Główny AK gen. Komorowski. W piśmie z lipca 1944 r. relacjonował:

W ciagu kwietnia 44 r. nie został przez TNRP wyznaczony nowy dowódca NSZ, gdyż w międzyczasie nastapiły w wewnątrz władz NSZ tarcia i rozdźwięki, które doprowadziły do zlikwidowania TNRP w drodze wewnętrznego zamachu dokonanego przez jeden odłam NSZ t.j. ONR i do utworzenia tzw. Rady Politycznej przy Dowództwie NSZ. Drugi odłam, wywodzący się z SN złożył na ręce D[owód]cy AK pisemny protest przeciwko poczynaniom i decyzjom ONR jako jednostronnym i niezgodnym ze statutem $\mathrm{TNRP}^{76}$.

Spróbujmy spojrzeć na opisane powyżej fakty od strony formalnoprawnej. Najpierw trzech członków prezydium TNRP, wbrew woli przewodniczącego i sekretarza generalnego Stypułkowskiego, pod nieobecność pozostałych pięciu członków tego ciała, jak też bez wiedzy działaczy zasiadających w 40-osobowej TNRP, „rozwiązało” radę. Następnie w miejsce „nieistniejącej” TNRP powołali oni Radę Polityczna przy Dowództwie NSZ ${ }^{77}$, która uzurpowała sobie wszystkie uprawnienia i zadania nieistniejacej rzekomo poprzedniczki. Stypułkowski miał więc wszelkie podstawy, by uznać działania liderów Grupy „Szańca” za nielegalne, sprzeczne ze statutem TNRP. W pełni uzasadniona jest też ocena gen. Komorowskiego, według którego w NSZ doszło do „wewnętrznego zamachu”, zaś „inicjatorzy tej akcji naruszyli obowiązujący porządek prawny"78. Władze PPP i dowództwo AK uznały Radę Polityczna przy Dowództwie NSZ za nielegalna, a wszystkie jej decyzje za bezprawne.

Stojący za pałacowym przewrotem działacze starali się przejąć inicjatywę. $\mathrm{Na}$ wieść o śmierci dotychczasowego Dowódcy NSZ dopiero co utworzona Rada Polityczna przy Dowództwie NSZ obwołała nowym dowódca mjr. Stanisława Nakoniecznikowa „Kmicica”79. Wybór nie był przypadkowy, ciążył na nim bowiem wyrok śmierci Wojskowego Sądu Specjalnego (WSS) za dezercję i rozbijanie jedności AK. Liderzy Grupy „Szańca” wybierając „Kmicica”, zyskiwali pewność, iż gen. Komorowski nie podejmie rozmów ze skompromitowanym oficerem, Dowódca NSZ z taka przeszłością zaś gwarantował zerwanie wszelkich kontaktów z AK.

Iłłakowicz, oddelegowany do pracy w sztabie mjr. Nakoniecznikowa w charakterze doradcy politycznego, czy raczej, jak sam twierdził, „faktycznie nadzorcy”, wydał następująca opinię o swym przełożonym: „Spędzałem z nim 2-5 godzin dziennie, przy czym zwykle był pod gazem, a czasem zupełnie pijany. Była to dla mnie bardzo nieprzyjemna funkcja. Czas schodził na niekończących się monologach ze wspomnień z przeszłości lub planów (zwykle

\footnotetext{
${ }^{76}$ SPP, A 434, NSZ, Załącznik do pisma do Pełnomocnika Rządu w Kraju z dn. 5 VII 1944 r.

77 W Radzie Politycznej przy Dowództwie NSZ znaleźli się: przewodniczący Władysław Marcinkowski, Wiktor Radziszewski, Otmar Wawrzkowicz, Jerzy Iłłakowicz i Witold Bayera.

78 SPP, A 434, NSZ, Załącznik do pisma do Pełnomocnika Rządu w Kraju z dn. 5 VII 1944 r.

${ }^{79}$ Mjr Stanisław Nakoniecznikow w NSZ używał stopnia podpułkownika. W literaturze występuje też pod nazwiskami Nakoniecznikoff i Nakoniecznikoff-Klukowski.
} 
nierealnych) na przyszłość. Jak był trzeźwy, był wcale sympatyczny i mnie lubił, AK nienawidził jak zarazy"80. Iłłakowicz - członek prezydium TNRP, a potem Rady Politycznej przy Dowództwie NSZ, jeden z czołowych liderów Grupy „Szańca” - przyznał, że o wyborze mjr. Nakoniecznikowa „Kmicica” nie zdecydowały doświadczenie czy zdolności dowódcze. ONR-owcy poszukiwali powolnej im marionetki, a nie samodzielnego, obdarzonego charyzma komendanta.

By nadać przewrotowi pozory legalności, zasiadający w Radzie Politycznej działacze sporządzili fałszywe, antydatowane rozkazy, wydane rzekomo przez płk. Kurcyusza „Żegotę”. Pierwszy z nich zwalniał ze stanowiska szefa sztabu NSZ ppłk. Świecińskiego. Szef sztabu, zgodnie z regulaminem NSZ, podczas nieobecności dowódcy przejmował jego obowiązki. Jednocześnie mjr Nakoniecznikow otrzymał nominację na pierwszego zastępcę Dowódcy NSZ, które to stanowisko w strukturze NSZ nie istniało. Kolejny podrobiony rozkaz, tym razem datowany na dzień śmierci płk. Kurcyusza, nadawał mjr. Nakoniecznikowowi stopień pułkownika i mianował go p.o. Dowódcy NSZ ${ }^{81}$. Liderzy Grupy „Szańca” przesłali następnie dowódcy AK pisma zawiadamiające o rezygnacji płk. Kurcyusza, pośmiertnym mianowaniu go generałem i powierzeniu tej funkcji dowódcy NSZ mjr. Nakoniecznikowowi, rzekomo wyznaczonemu na następcę przez zmarłego płk. Kurcyusza. Generał Komorowski „nie przyjął do wiadomości mianowania Żegoty generałem, jak również zatwierdzenia na stanowisku Dow.cy NSZ ob. Kmicica z powodu niewłaściwej instytucji zatwierdzającej t.zw. Rady Politycznej przy Dowództwie NSZ, jak również $\mathrm{z}$ racji wniesienia $\mathrm{w}$ tej sprawie sprzeciwu odłamu wywodzącego się z SN"82.

Od podpisania umowy scaleniowej upłynęły niemal dwa miesiace, a vacat na stanowisku Dowódcy NSZ uniemożliwiał rozpoczęcie włączania NSZ do AK. W obliczu klinczu, jaki zapanował między ONR-owcami a działaczami SN związanymi ze Stypułkowskim, gen. Komorowski 2 V 1944 r. mianował dotychczasowego szefa sztabu NSZ ppłk. Świecińskiego „Tuwara” p.o. pełnomocnika dowódcy AK do spraw NSZ i tymczasowym dowódcą NSZ, o czym powiadomił obie rywalizujące w NSZ frakcje. W przesłanych pismach zaznaczył, że jest to doraźne rozwiązanie, zaś Komendant Sił Zbrojnych w Kraju oczekuje na kandydata wspólnie wytypowanego przez przywódców obu środowisk tworzących NSZ. Obejmujac stanowisko, ppłk Świeciński „otrzymał specjalne zlecenie niedopuszczenia do rozłamu w oddziałach wojskowych NSZ"83. Tego samego dnia ppłk Świeciński udał się na spotkanie z przedstawicielami Rady Politycznej, w którego trakcie mjr Nakoniecznikow stał nad siedzącym „Tuwarem” z pistoletem w ręku ${ }^{84}$. „Argumentacja” odniosła

\footnotetext{
80 J.O. Iłłakowicz, op. cit., s. 97.

81 W.J. Muszyński, op. cit., s. 312.

${ }^{82}$ SPP, A 434, NSZ, Załącznik do pisma do Pełnomocnika Rządu w Kraju z dn. 5 VII 1944 r.

${ }^{83}$ Ibidem.

${ }^{84}$ K. Komorowski, Polityka i walka..., s. 425.
} 
oczekiwany skutek. Następnego dnia ppłk Świeciński złożył na ręce dowódcy AK pisemną rezygnację z przyjętych dzień wcześniej funkcji.

$6 \mathrm{~V} 1944 \mathrm{r}$. do KG AK wpłynął meldunek od pierwszego zastępcy szefa sztabu NSZ mjr. Albina Raka „Lesińskiego" 85 informujący, że po śmierci „Żegoty” i rezygnacji „Tuwara” zgodnie z regulaminem NSZ zastępczo przejął on obowiązki Dowódcy NSZ. Pismem tym zwracał się do komendanta AK o odebranie od niego i członków sztabu NSZ przysięgi AK i dalsze rozkazy. Generał Komorowski przyją meldunek „Lesińskiego”, lecz wstrzymał się od wydawania jakichkolwiek pisemnych poleceń, licząc, że obie frakcje dojda $\mathrm{w}$ końcu do porozumienia w sprawie kandydata na dowódcę. Tego samego dnia mjr Rak wydał adresowany do członków NSZ rozkaz, w którym napisał: „Jako najstarszy kolejno funkcja oficer NSZ, stosownie do rozkazu [...] regulującego organizację hierarchii Dowództwa NSZ - z dniem dzisiejszym obejmuję zastępczo obowiązki Dowódcy NSZ"86.

Równolegle do KG AK nadeszło pismo Rady Politycznej przy Dowództwie NSZ i mjr. Nakoniecznikowa z prośbą o spotkanie z dowódca AK. Ten stanowczo odmówił. Jego stosunek do oenerowskich władz NSZ, ukonstytuowanych w wyniku pałacowego przewrotu, oddaje język ówczesnych dokumentów. Nazwę „Rada Polityczna przy Dowództwie NSZ” konsekwentnie poprzedza określenie „tak zwana”, przy pseudonimie „Kmicic” brak jest jakichkolwiek funkcji, podkreśla się zaś wyrok za dezercję. W połowie maja 1944 r. gen. Komorowski kolejny raz wezwał obie frakcje polityczne w NSZ do zawarcia kompromisu, wyznaczył dwutygodniowy termin na wspólne wskazanie dowódcy NSZ i zapowiedział, że $\mathrm{w}$ razie braku porozumienia sam przejmie inicjatywę ${ }^{87}$.

19 maja mjr Rak zakomunikował podkomendnym z NSZ, że dowódca AK przyjął do wiadomości objęcie przez niego dowództwa nad NSZ, napiętnował „Kmicica” za bezpodstawne uzurpowanie sobie praw do dowodzenia i zapowiedział, że „ppłk Kmicic będzie pociagnięty niezwłocznie do odpowiedzialności przez Komendanta Sił Zbrojnych w Kraju za szerzenie zamętu w Narodowych Sił Zbrojnych i nakazał natychmiast przerwać wszelką łączność organizacyjna z t.zw. "Dowództwem płk. Kmicica»", w końcu ostrzegł, że niepodporządkowanie się rozkazom zostanie potraktowane jako działanie dywersyjne skierowane przeciwko polskiemu wojsku ${ }^{88}$.

Odpowiedź ze strony Grupy „Szańca” nadeszła 21 maja. Nakoniecznikow wydał rozkaz stwierdzający, iż „NSZ są częścią składową Armii Krajowej”, niemniej zachowuja pełną odrębność, a jednocześnie zabraniał „dekonspirowania Komend i oddziałów NSZ przed przedstawicielami AK” i zastrzegł dla

\footnotetext{
${ }^{85}$ Mjr Albin Rak w NSZ występował jako podpułkownik.

${ }^{86}$ Rozkaz oficerski nr 7, 6 V 1944, sygnowany: Zastępca Szefa Sztabu NSZ Lesiński, w: Narodowe Sity Zbrojne..., t. II: NSZ-AK, oprac. L. Żebrowski, Warszawa 1996, s. 76-77.

${ }^{87}$ SPP, A 434, NSZ, Załącznik do pisma do Pełnomocnika Rządu w Kraju z dn. 5 VII 1944 r.

${ }^{88}$ Armia Krajowa Komenda Główna NSZ, Rozkaz specjalny nr 16, 19 V 1944, w: Narodowe Sity Zbrojne..., t. II, s. 37-39.
} 
siebie decyzję o ewentualnej, przyszłej współpracy z $\mathrm{AK}^{89}$. Instrukcja „Kmicica” stwierdzała zatem, że NSZ zostały scalone z AK, a jednocześnie nakazywała zataić struktury i działania NSZ przed AK i zabraniała wykonywania rozkazów Komendanta Sił Zbrojnych w Kraju. Nakoniecznikow interpretował pojęcie „scalenie” w sposób radykalnie odmienny od tego, jak rozumieli je Komendant Główny AK i Naczelny Wódz. Dwa dni później - 23 maja - oenerowska bojówka napadła na por. Witolda Borkowskiego i mjr. Danielewicza, którzy przybyli do Kielc z rozkazami informujacymi o nominacji „Leśniewskiego” na p.o. Komendanta NSZ. „Aresztowanych” tego samego dnia odbił scalony z AK oddział NSZ ${ }^{90}$.

25 maja spotkała się grupa oenerowskich działaczy pod przewodnictwem Wawrzkowicza. Zebrani, bez żadnych formalnych podstaw, uznali się za „prezydium TNRP”, przegłosowali wotum nieufności wobec Stypułkowskiego i zdecydowali o postawieniu go oraz por. Michałowskiego ${ }^{91}$ przed „sądem organizacyjnym” za złamanie umowy frondy SN z Grupa „Szańca”, chęć „oddania NSZ do dyspozycji SN”, podjęcie rozmów z AK oraz „prowadzenie rozmów i narad dyskredytujących Polaka Narodowca z reprezentantem obcych agentur oraz masonerii, a mianowicie przedstawicielem światowego żydostwa p. R.” ${ }^{2}$ „R” to Józef Retinger - sekretarz i doradca polityczny gen. Sikorskiego. W 1944 r. zrzucony został do okupowanej Polski jako kurier polityczny, którego zadaniem było wybadanie nastrojów panujących w podziemiu i naświetlenie liderom PPP możliwych scenariuszy rozwoju sytuacji. Retinger to Polak, którego żydowscy przodkowie przeszli na katolicyzm na początku XIX w. Posiadał on rozległe kontakty w świecie anglosaskim i był związany z polskimi i brytyjskimi kręgami rządowymi. To wystarczyło, by oenerowcy uznali go za reprezentanta bliżej nieokreślnego „światowego żydostwa”. Przekonanie, że prowadzenie rozmów z Żydem lub masonem jest dyskredytujące dla „Polaka - Narodowca”, w związku z czym powinno być podstawą wyroku sądu specjalnego, wiele mówi o światopoglądzie członków samozwańczego prezydium TNRP. Oenerowcy dodatkowo bezpodstawnie oskarżyli por. Michałowskiego o „patronowanie akcji współpracy z Niemcami oddziałów NOW podszywajacych się pod NSZ (oddziałów tzw. Toma)”93.

${ }^{89}$ Komunikat, Narodowe Siły Zbrojne, Dowództwo, L.dz. 105/44, 21 V 1944 r. sygnował: p.o. dowódca NSZ Kmicic, w: Narodowe Sity Zbrojne..., t. III: NSZ-ONR, oprac. L. Żebrowski, Warszawa 1996, s. 40.

${ }^{90}$ Rozkaz oficerski nr 11, 20 VI 1944, sygnował p.o. Komendant NSZ Lesiński, w: Narodowe Sity Zbrojne..., t. II, s. 76-77.

${ }^{91}$ August Michałowski był działaczem SN, jednym z liderów frondystów w 1942 r., bliskim współpracownikiem Stypułkowskiego, a w 1944 r. zwolennikiem pełnego scalenia z AK.

${ }^{92}$ K. Komorowski, Polityka i walka..., s. 426.

${ }_{93}$ Protokół z posiedzenia Prezydium TNRP, 25 V 1944, w: Narodowe Sity Zbrojne..., t. III, s. 41-45. Wymieniony w dokumencie „Tom” to Hubert Jura „Tom”. Współpracował on z Gestapo i czynił to za wiedzą i przyzwoleniem Otmara Wawrzkowicza, a na przełomie 1944 i 1945 r. został oficerem Brygady Świętokrzyskiej NSZ. Oenerowcy oskarżyli zatem działacza SN - zwolennika scalenia z AK - por. Michałowskiego o czyny przez siebie popełnione. 
Bezprawne oddanie pod oenerowski „sąd” ważnych działaczy konspiracyjnego $\mathrm{SN}$ - partii stanowiącej jeden z czterech filarów porozumienia politycznego, na jakim opierały się rząd polski w Londynie i PPP - było równoznaczne z zakwestionowaniem legalności instytucji państwa polskiego. W tym momencie sprawa przestawała mieć charakter wyłącznie wojskowy i stawała się problemem politycznym.

W końcu maja upłynął czas, jaki Komendant Sił Zbrojnych na Kraj wyznaczył obu frakcjom NSZ na wspólne wskazanie dowódcy. Po tym terminie Stypułkowski powiadomił dowódcę AK, „że do porozumienia nie doszło, a przeciwnie do pogłębienia różnic" ${ }^{94}$. Jako że szansa na osiagnięcie konsensu między politykami zasiadającymi w TNRP spadła do zera, gen. Komorowski nie odroczył wejścia w życie umowy scaleniowej. 5 VI 1944 r. mjr Rak „Lesiński” został przyjęty przez gen. Komorowskiego, zaprzysiężony i wyposażony w instrukcje dotyczące przebiegu akcji scaleniowej. Opublikowany tego dnia w „Biuletynie Informacyjnym” rozkaz „Bora” głosił:

został dn. 7 III 44 podpisany układ o podporządkowaniu i wcieleniu NSZ do AK. W międzyczasie jednak wewnętrzne tarcia w kierownictwie NSZ doprowadziły do tego, że dotychczas nie został dokonany żaden praktyczny krok w kierunku realizacji tego układu. Wskutek tego akcja wojskowa NSZ, mimo formalnego podporządkowania - nie była i nie jest przez AK ani kierowana, ani kontrolowana. Nie moge tolerować dłużej tego stanu szkodliwego dla całości wysiłku wojskowego. Nie czekając na wykrystalizowanie się stosunków w kierownictwie NSZ zarządzam rozpoczęcie wcielania oddziałów do AK i w tym celu wyznaczam z pośród oficerów NSZ p.o. komendanta, któremu polecam przeprowadzenie scalenia. Wzywam wszystkie oddziały NSZ do karnego podporządkowania się wyznaczonemu przeze mnie komendantowi ${ }^{95}$.

Tego samego dnia treść rozkazu została przekazana do odłamów NSZ.

O ile wcześniej można było mówić o frakcjach w ramach NSZ, to mianowanie p.o. dowódcy NSZ przez gen. Komorowskiego przypieczętowało rozpad formacji na dwie odrębne organizacje: tę uznającą zwierzchność mjr. Raka, określaną w historiografii jako NSZ-AK oraz oenerowska, przeciwstawiająca się scaleniu, występującą w literaturze jako NSZ-ZJ lub NSZ-OP.

10 czerwca Rada Polityczna przy Dowództwie NSZ wydała, w formie plakatu, komunikat oskarżający Komendanta Sił Zbrojnych na Kraj o umyślne zerwanie rozmów i uznający jego rozkaz wyznaczający oficera odpowiedzialnego za scalenie NSZ z AK za nielegalny. Dokument informował, że na stanowisko to dowódca AK wybrał „byłego oficera NSZ, rebelianta, skazanego przez sąd wojennych przy Dowództwie NSZ na karę śmierci, degradację i utratę praw obywatelskich i honorowych". Komunikat nakazywał członkom NSZ zbojkotować scalenie i stwierdzał, iż wobec „wypadków które nadchodza,

${ }_{94}$ SPP, A 434, NSZ, Załącznik do pisma do Pełnomocnika Rządu w Kraju z dn. 5 VII 1944 r.

${ }^{95}$ Rozkaz Nr 173 Komendanta Sit Zbrojnych w Kraju, „Biuletyn Informacyjny”, (Warszawa) 8 VI 1944, nr 22-23 (229-230). 
wobec szerzącej się komuny i anarchii, NSZ mogą stać się jedyną ostoją bytu Narodu i Państwa Polskiego"96.

Dwa dni później gen. Komorowski wysłał depeszę powiadamiajacą Naczelnego Wodza o działaniach oenerowców:

Po podpisaniu umowy scaleniowej z NSZ radykalne, nieodpowiedzialne czynniki polityczne ONR doprowadziły w drodze zamachu do likwidacji Tymczasowej Narodowej Rady Politycznej i wyłoniły spośród siebie tzw. Radę Polityczną przy dowództwie NSZ. Rada ta po śmierci Żegoty wyznaczyła na komendanta dezertera z AK całkowicie u nas zdyskwalifikowanego. [...] Przez samozwańczy sąd, niby „w imieniu Rzeczypospolitej”, opublikowany został wyrok śmierci na wyznaczonym przeze mnie p.o. Komendanta NSZ. Wyrok ten bezprawnie zatwierdziła t.zw. Rada Polityczna przy Dowództwie NSZ. Prócz tego rozpoczęto ze strony tych czynników akta terroru w stosunku do lojalnych wobec mych zarządzeń członków NSZ. Zbrodnicze zaślepienie polityczne tej Rady doprowadzić może do nieobliczalnych następstw. Wydałem rozkaz przyjmowania do AK żołnierzy NSZ, natomiast nie będę pertraktował z ich politycznym kierownictwem. Zwróciłem się do Delegata Rządu z prośbą o wyciagnięcie konsekwencji prawnych w stosunku do wszystkich, którzy dopuścili się bezprawia ${ }^{97}$.

13 VI 1944 r. przywódcy NSZ-ZJ opublikowali w piśmie „Narodowe Siły Zbrojne" zbiór tekstów będący mieszaniną informacji prawdziwych, półprawd i kłamstw tak dobranych, by ukazać NSZ-ZJ jako niewinną ofiarę agresywnej AK i zdrajców z SN. Z otwierającego artykułu, pt. Pod osad opinii, wynika, jakoby dowódcy NSZ-owcy zawsze szczerze pragnęli „uczciwego scalenia”, opanowana zaś przez „czynniki antynarodowe, działające wbrew interesom Polski” AK rozmyślnie sabotowała scalenie i podjęła je dopiero „pod naciskiem Naczelnego Wodza”. Dowództwo AK to „mafia”, a niedawni partnerzy z SN to „pewne koła partyjniaków i warchołów, które chciały uczynić z NSZ bojówkę partyjną"98. Bezpośrednio po tym wprowadzaniu ONR-owcy umieścili List otwarty do Komendanta Polskich Sit Zbrojnych w Kraju, w którym zapewniali o swej głębokiej trosce o „los tego co nam jest najdroższe, o przyszłość Polski”99. Po czym przeszli do oskarżeń dowódcy AK o torpedowanie scalenia przez celowe niepodejmowanie rozmów z „Kmicicem”, określanym tu jako „Dowódca NSZ i pełnomocnik Pana Generała dla spraw NSZ”. W Liście otwartym nie ma słowa o bezprawnym „rozwiąaniu TNRP” i „przejęciu” jej uprawnień przez Radę Polityczną przy Dowództwie NSZ, faktycznym rozpadzie NSZ czy ciążącym na „Kmicicu” wyroku AK. Wśród załączonych dokumentów znalazł się natomiast wyrok śmierci na mjr. Raka skazanego

\footnotetext{
${ }_{96}$ SPP, A 434, NSZ, Narodowe Siły Zbrojne. Komunikat, sygnowane: 10 VI 1944 Rada Polityczna przy Dtwie NSZ, k. 68.

${ }_{97}$ Ibidem, Depesza gen. Komorowskiego do gen. Sosnkowskiego z 12 VI 1944 r. odebrana 25 VI 1944, k. 46.

${ }^{98}$ Pod Sad Opinii, „Narodowe Siły Zbrojne”, (Warszawa) 13 VI 1944, nr 7.

${ }^{99}$ List otwarty do Komendanta Polskich Sit Zbrojnych w Kraju, „Narodowe Siły Zbrojne”, (Warszawa) 13 VI 1944, nr 7.
} 
za niepodporządkowanie się sfałszowanemu rozkazowi dowódcy NSZ płk. Kurcyusza „Żegoty”, przekazującemu dowództwo mjr. Nakoniecznikowowi „Kmicicowi”. „Wyrok” datowany jest na 2 VI 1944 r., teoretycznie więc wydany został trzy dni przed zaprzysiężeniem mjr. Raka przez Komendanta Sił Zbrojnych na Kraj. Antydatowanie przez NSZ-ZJ dokumentu służyło wykazaniu, iż „sąd” skazał członka NSZ, a nie oficera AK. Pod wyrokiem widnieje notka informująca, iż Rada Polityczna przy Dowództwie NSZ jest gotowa unieważnić wyrok na „ppłk. Lesińskiego”, o ile ten by „wyraził czynny żal, czyli odwołał wszystkie rozkazy, zaprzestał w przyszłości jakiejkolwiek akcji na szkodę NSZ i podporządkował się p.o. D[owód]cy NSZ”'100.

Z perspektywy przywódców PPP dokument ten miał charakter kuriozalny. Po pierwsze, nosił znamiona szantażu - mógł być bowiem unieważniony, gdyby „skazany” odwołał wydane już rozkazy. Po drugie, o ewentualnym odwołaniu wyroku miał decydować nie sąd, lecz ciało partyjne, jakim była Rada Polityczna przy Dowództwie NSZ. Po trzecie, rzecz najistotniejsza skazujący na śmierć mjr. Raka „Lesińskiego” Sąd Wojenny przy Dowództwie NSZ to nie WSS utworzony w oparciu o kodeksy zatwierdzone przez rząd RP na uchodźstwie ${ }^{101}$, a co za tym idzie „sąd NSZ” nie był sądem, tylko samozwańczym, partyjnym trybunałem. Jego członkowie wydając wyrok „w imieniu Rzeczypospolitej” na oficerze KG AK, sami dopuszczali się ciężkiego przestępstwa ${ }^{102}$.

100 Wyrok zaoczny w imieniu Rzeczypospolitej Polskiej, „Narodowe Siły Zbrojne”, (Warszawa) 13 VI 1944, nr 7.

101 Sądownictwo PPP powstało w oparciu o Przepisy Materialne oraz Kodeks Sąów Kapturowych. Dokumenty te opracowano w okupowanym kraju w maju 1940 r. i zostały zatwierdzone przez władze na uchodźstwie. Przepisy Materialne określały pięć najważniejszych przestępstw sądzonych przez podziemny wymiar sprawiedliwości. Kodeks Sądów Kapturowych ustalił skład sędziowski, procedurę sądową i tryb wykonywania wyroków.

102 Ze wspomnień Jerzego O. Iłłakowicza wynika, że był on wraz z Otmarem Wawrzkowiczem, Stanisławem Kasznica i Kazimierzem Gluzińskim członkiem czteroosobowego „specjalnego sądu wojennego NSZ”. Pod wyrokiem na „Lesińskiego” widnieją podpisy: „T. Żubr”, „M. Ryś”, „S. Grabowiec” i „J. Ostoja”. Być może za tymi pseudonimami ukrywała się powyższa czwórka. W oparciu o istniejącą literaturę przedmiotu nie da się zweryfikować tej hipotezy. Nie można też wykluczyć, że Sąd Wojenny przy Dowództwie NSZ nigdy nie istniał i wymyślono go wyłącznie dla potrzeb propagandowych, a „T. Żubr”, „M. Ryśs”, „S. Grabowiec” i „J. Ostoja” to postacie fikcyjne. Iłłakowicz opisał zwyczaje panujące w „specjalnym sądzie wojennym”. Czterej „sędziowie” zapoznawali się z raportami, po czym przeprowadzali głosowanie. Jeśli jego wynik był jednomyślny, zapadała decyzja o wykonaniu „wyroku”. Brak jednomyślności nie oznaczał uwolnienia od oskarżeń, wręcz przeciwnie, sprawa „podejrzanego” mogła być wielokrotnie poddawana pod głosowanie, aż do uzyskania jednomyślności. Procedura ta nie przewidywała złożenia wyjaśnień przez oskarżonego i nie uczestniczył w niej jego obrońca. Z czwórki „sędziów” jedynie Kasznica miał wykształcenie prawnicze. Tryb postępowania tego ciała przypominał praktyki trybunałów rewolucyjnych lub grup mafijnych. Zob. Wspomnienia Jerzego Olgierda Zawiszy-Ittakowicza, w: W.J. Muszyński, op. cit., s. 508. 
Wśród opublikowanych w prasie NSZ-ZJ tekstów znalazły się kopie dwóch autentycznych dokumentów: umowy scaleniowej NSZ z AK z 7 III 1944 r. i rozkazu Komendanta Sił Zbrojnych na Kraj z 5 VI 1944 r wyznaczającego „p.o. komendanta” NSZ. Ich dołączenie nadawało całości większą wiarygodność. Zamykało je zmanipulowane „Chronologiczne zestawienie faktów”, w którym obok prawdziwych znalazły się następujące spreparowane informacje:

- rzekome powołanie przez TNRP Rady Politycznej przy Dowództwie NSZ i przekazanie jej zwierzchnictwo nad NSZ;

- rzekome mianowanie „Kmicica” przez „Żegotę” swym zastępca;

- rzekome powierzenie przez „Żegotę”, przed śmiercia, obowiązków dowódcy NSZ „Kmicicowi”;

- uznanie, w oparciu o wyżej wymienione nieprawdziwe fakty, zastępcy szefa sztabu NSZ „Lesińskiego” za „samozwańczego dowódcę NSZ”;

- mianowanie „Lesińskiego” p.o. komendantem NSZ, pomimo rzekomo skazania go wcześniej na śmierć przez „sąd wojenny NSZ” ${ }^{103}$.

Całość została skomponowana tak, by udowodnić uprawnienia Rady Politycznej przy Dowództwie NSZ do obsadzania stanowiska dowódcy NSZ, wykazać, iż mjr Nakoniecznikow „Kmicic” legalnie objął funkcję oraz by winą za fiasko scalenia obciążyć AK. Wywód zaś opierał się na fałszywym założeniu, że instytucjonalno-prawne zakotwiczenie NSZ-ZJ oraz AK jest identyczne.

15 czerwca - dwa dni po ukazaniu się numeru „Narodowych Sił Zbrojnych” z powyższymi tekstami - mjr Rak „Lesiński” w środku dnia został porwany z ulicy przez bojówkę NSZ-ZJ i wywieziony do lokalu na przedmieściach Warszawy, gdzie czekali na niego dowódca NSZ-ZJ mjr Nakoniecznikow i członkowie sztabu: ppor. Wiktor Radziszewski „Wiktor”104 i por. Marcinkowski „Jaxa”. Tam „Odczytano mu wyrok śmierci, zagrożono natychmiastowym wykonaniem przez znajdująca się w sąsiednim pokoju bojówkę o ile nie podpisze przedłożonych mu, a poprzednio zredagowanych już dokumentów” 105. W pierwszym, adresowanym do Dowódcy NSZ „Kmicica”, „Lesiński” „przyznawał się”, że oszukany przez zwolenników scalenia: Pacholczyka, Stypułkowskiego i Michałowskiego „nieświadomie” obją funkcję p.o. Dowódcy NSZ. Po „uświadomieniu” mu błędów zdecydował się podporządkować „Kmicicowi jako jedynie legalnemu p.o. Dowódcy NSZ”106. Adresatem drugiego, niemal identycznego, pisma był komendant $\mathrm{AK}^{107}$. Trzeci dokument miał charakter oświadczenia stwierdzającego, iż mjr Rak przybył na odprawę z „Kmicicem” dobrowolnie, okazane mu rozkazy sygnowane jego

${ }^{103}$ Chronologiczne zestawienie faktów, „Narodowe Siły Zbrojne”, (Warszawa) 13 VI 1944, nr 7.

${ }_{104}$ Ppor. Wiktor Radziszewski „Wiktor” w NSZ posługiwał się stopniem majora.

105 SPP, A 434, NSZ, Załącznik do pisma do Pełnomocnika Rządu w Kraju z dn. 5 VII 1944 r.

106 Ibidem, Załącznik nr 1, do rozkazu oficerskiego nr 8, w którym „Kmicic” kieruje sprawę „Lesińskiego” do „Sądu Komendy Głównej NSZ” do ponownego rozpatrzenia, 15 VI 44, k. 64.

${ }^{107}$ Ibidem, Załącznik nr 2, do rozkazu oficerskiego nr 8, w którym „Kmicic” kieruje sprawę „Lesińskiego” do „Sądu Komendy Głównej NSZ” do ponownego rozpatrzenia, 15 VI 44, k. 64. 
pseudonimem „od dnia 6 maja w dużej części były jemu nieznane. Poza nim wydano rozkazy z jego podpisem, bez jego wiedzy rozkazy godzace w całość i zwartość NSZ”. W związku z czym anuluje on „zupełnie dobrowolnie i odwołuje rozkazy przez siebie podpisane i całkowicie podporządkowuje się p.o. Dowódcy NSZ p. płk Kmicicowi”108. W oparciu o tak uzyskane dokumenty dowódca NSZ-ZJ skierował sprawę „Lesińskiego” do ponownego rozpatrzenia przez „Sąd Komendy Głównej NSZ” ${ }^{109}$. Wobec groźby zabójstwa mjr Rak podpisał przygotowane przez porywaczy maszynopisy oświadczeń, po czym został uwolniony. Tego samego dnia złożył on gen. Komorowskiemu meldunek opisujacy szczegóły porwania, podkreślił, że wymuszone bronia podpisy uważa za nieważne i zamierza dalej pełnić powierzona mu funkcję, na co dowódca AK wyraził zgodę. 20 czerwca „Lesiński” informował: „Grupa Kmicica wydała na mnie wyrok śmierci, który jest zwykła groźbą mordu, mający na celu zmuszenie mnie do niewykonania rozkazu Komendanta Sił Zbrojnych w Kraju [...]. Wszystkich dających posłuch samozwańczemu «Dowództwu Kmicica» będę na mocy specjalnego upoważnienia Komendanta Sił Zbrojnych w Kraju usuwał z szeregów NSZ, co jest równoznaczne z usunięciem z szeregów Armii Polskiej bez prawa powrotu"110.

Oenerowscy przywódcy uprowadzając i terroryzując oficera KG AK, przekroczyli Rubikon. 10 dni przed porwaniem otrzymali ze sztabu AK informację o zaprzysiężeniu mjr. Raka i powierzeniu mu przez Komendanta Sił Zbrojnych w Kraju misji scalenia NSZ. Nie mogli twierdzić, że nie wiedzieli, co uczynili. Bojówka, podlegająca ugrupowaniu politycznemu kwestionującemu prerogatywy władz PPP i sprzeciwiającemu się utworzeniu jednolitej podziemnej armii, dokonała zamachu na oficerze wykonujacym misję powierzoną mu przez najwyższego dowódcę WP w okupowanym kraju. Liderzy NSZ-ZJ przekroczyli granicę między kwestionowaniem prawomocności poszczególnych decyzji najwyższych władz polskich $\mathrm{w}$ okupowanym kraju a otwartym wystapieniem przeciwko nim. Sprawa o wymiarze politycznym, z powodu użycia przemocy, nabrała charakteru kryminalnego. Z punktu widzenia władz PPP jedynie bezwarunkowe ustapienie mjr. Nakoniecznikowa i skrucha członków Rady Politycznej przy Dowództwie NSZ mogłyby załagodzić sytuację. ONR-owcy byli jednak najdalsi od takiego rozwiązania. Ich ambicję stanowiło przejęcie kontroli nad całymi NSZ, a w kolejnych krokach przechwycenie rządów w Polsce.

Od pierwszych dni czerwca istniały więc już dwa dowództwa NSZ aspirujące do kierowania strukturami terenowymi organizacji. Wysłannicy obu

108 Ibidem, Załącznik nr 3. Oświadczenie sygnowane „Misiewicz”, „Kmicic”, „Lesiński” załączone do rozkazu oficerskiego nr 8, w którym „Kmicic” kieruje sprawę „Lesińskiego” do „Sądu Komendy Głównej NSZ” do ponownego rozpatrzenia, 15 VI 44, k. 65.

109 Ibidem, Rozkaz oficerski nr 8, w którym „Kmicic” kieruje sprawę „Lesińskiego” do „Sądu Komendy Głównej NSZ” do ponownego rozpatrzenia, 15 VI 44, k. 101.

110 Armia Krajowa, Komenda Główna NSZ, 20 VI 1944, Rozkaz oficerski Nr 11, dokument sygnowany p.o. Komendant NSZ Lesiński, w: Narodowe Sity Zbrojne..., t. II, s. 76-77. 
środków docierali do komend okręgów, starając się je sobie podporządkować. NSZ-ZJ przejął pełną kontrolę jedynie nad Okręgiem Krakowskim NSZ. W okręgach Warszawa Miasto, Warszawa Powiaty, Kielce, Białystok i Częstochowa funkcjonowały jednocześnie komendy okręgów NSZ-AK i NSZ-ZJ, przy czym komendy oenerowskie uzyskały znacznie mniejsze wpływy od ich akowskich odpowiedników. Pozostałe okręgi (Lublin, Rzeszów, Podlasie, Pomorze, Poznań, Łódź, Śląsk, Mazowsze Północ, Lwów) podporządkowały się sztabowi NSZ-AK. Należy przyznać rację Muszyńskiemu, według którego zwolennicy scalenia „zdołali przejąć większość siatki terenowej i niemal wszystkie dowództwa okręgów. Wpływy OP okazały mniejsze, a jej działacze mniej skuteczni i to mimo wielkiej akcji propagandowej i dezinformacyjnej w prasie, ulotkach [...] które oficjalnie podtrzymywały wersję, że NSZ-OP scalił się z AK"111.

21 VI 1944 r. komendant NSZ-ZJ mjr Nakoniecznikow poinformował podkomendnych, jakoby Niemcy przechwycili jeden z rozkazów „Lesińskiego”. Ostrzegał członków NSZ-ZJ, iż „Zachodzi obawa rozpracowania przez Gestapo pewnych grup organizacji NSZ. Polecam zerwać kontakty z ludźmi i komórkami, które miały jakąkolwiek łączność z kol. Lesińskim”"12. Liderzy Grupy „Szańca” uciekli się do kłamstwa w celu odizolowania mjr. Raka od siatki terenowej NSZ-ZJ. Rozkazem tym NSZ-AK uznane zostały za obca organizację, w związku z czym członkowie NSZ-ZJ mieli natychmiast zerwać z nią wszelkie kontakty. „Kmicic” nakazywał oddawanie pod „sąd doraźny” i zastosowanie „najostrzejszych środków zaradczych” wobec osób kwestionujaccych autorytet „komendanta NSZ”, dowództwa lub działających na korzyść „czynników zewnętrznych” ${ }^{113}$. Zapewne na mocy tego właśnie rozkazu zamordowanych zostało później czterech oficerów NSZ-AK, aktywnie działajacych na rzecz scalenia ${ }^{114}$.

Mechanizm porachunków mafijnych w połączeniu z obsesyjnym poszukiwaniem „zdrajców” doprowadził w końcu ONR-owskich „sędziów” do wydania „wyroku” na mjr. Nakoniecznikowie „Kmicicu”, którego posądzono o chęć podporządkowania NSZ-ZJ „komunistom” z PAL. Wraz z „Kmicicem” zamordowany został szef sztabu Okręgu Częstochowa NSZ-ZJ por. Włodzimierz Żaba „Żniwiarz”. Odpowiedzialna za te mordy była „egzekutywa” ONR kierowana przez Wawrzkowicza i Huberta Jurę „Toma” - ludzi utrzymujących stały kontakt z szefem Gestapo w Radomiu SS-Hauptsturmführerem Paulem

111 W.J. Muszyński, op. cit., s. 318.

${ }_{112}$ Rozkaz szczególny 1/S/44, sygnowany: p.o. Komendant NSZ Kmicic, 21 VI 1944, w: Narodowe Sity Zbrojne..., t. III, s. 57-58.

${ }^{113}$ Ibidem.

${ }^{114}$ Zamordowani zostali: kierownik wydziału ogólnoorganizacyjnego sztabu NSZ-AK ppor. Władysław Pacholczyk „Adam”, szef oddziału II (wywiad NSZ) ppor. Witold Gostomski, dowódca „Akcji Specjalnej” por. (w NSZ kpt.) Andrzej Czajkowski „Chwalibóg”, szef „Akcji Specjalnej” NSZ-AK i szef wywiadu Okręgu Częstochowa NSZ-AK kpt. Stanisław Żak. 
Fuchsem. Jesienią 1944 r. w środowisku NSZ-ZJ za zdrajców uznawano członków AK-NSZ, sądzenie i karanie ich zaś oddano w ręce współpracowników Gestapo. Po śmierci „Kmicica” nowy Dowódca NSZ, płk (?) Zygmunt Broniewski poinformował podkomendnych przepełnionym patosem rozkazem:

18 października [1944 r.] nieznane ręce targnęły się na życie ś.p. płk. Kmicica kula przecięła pasmo jego żołnierskiego życia. Ś.p. płk Kmicic zawsze wierny idei wysoko niósł zawsze sztandar NSZ. [...] Swymi czynami wykazał jak bardzo rozumiał w pierwszym rzędzie grozę niebezpieczeństwa komunistycznego dla Polski. Sam dźwięk jego nazwiska bojowego powodował ataki wściekłości sług Stalina. [...] I tu, w tym środowisku musimy szukać sprawców śmierci ś.p. płk. Kmicica. Żołnierze NSZ potrafią pomścić śmierć Swego Dowódcy na wrażej Komunie ${ }^{115}$.

W tym samym tonie utrzymany był opublikowany na łamach „Szańca” nekrolog ${ }^{116}$. Przywódcy NSZ-ZJ oddali publicznie hołd człowiekowi, którego zastrzelili za kontakty z radykalnie lewicowa PAL, za mord obwinili komunistów, a podkomendnym nakazali dokonać zemsty na „wrażej komunie”. Czynów tych dopuścili się ludzie, którzy pisali o sobie, iż są elitą narodu, z racji przymiotów duchowych, intelektualnych i ideologicznego zaangażowania predestynowani do rządzenia Polakami.

Mord na własnym dowódcy, mordy na członkach własnej organizacji, porwania, fałszowanie dokumentów, obarczanie innych wina za popełniane przez siebie zabójstwa - w trudnym, niekiedy brutalnym świecie polskiego podziemia okresu II wojny światowej poza NSZ-ZJ jedynie PPR dopuszczała się podobnych działań ${ }^{117}$.

Do poczynań przywódców NSZ-ZJ szybko odniósł się Naczelny Wódz gen. Sosnkowski:

${ }_{115}$ Rozkaz specjalny NR 2/Z/44, sygnowany: p.o. Komendant Główny NSZ płk Bogucki, 20 X 1944, w: Narodowe Sity Zbrojne..., t. III, s. 79-80.

116 „Szaniec” 1944, nr 52.

117 Jedyny, obok zabójstwa dowódcy NSZ-ZJ mjr. Nakoniecznikowa „Kmicica”, znany przypadek mordu popełnionego przez członków dużej organizacji podziemnej na własnym dowódcy to zabójstwo z 28 XI 1942 r. I sekretarza PPR Marcelego Nowotki. Według Władysława Gomułki dokonał go członek Sztabu Głównego GL Zygmunt Mołojec z polecenia swego brata - dowódcy GL Bolesława Mołojca. Po wewnętrznym dochodzeniu bojówka PPR zastrzeliła braci Mołojców. Piotr Gontarczyk zauważył, że okoliczności śmierci Nowotki pozostaja niewyjaśnione. Według niego mogła być efektem albo porachunków partyjnych, albo operacji niemieckich służb specjalnych. Nie wykluczył też, iż była to akcja AK. Jeśli przyjąć, że Nowotko zginął w wyniku akcji bojówki PPR (a do tej wersji się przychylam), to z rąk działaczy PPR-GL śmierć poniosło trzech członków władz PPR. Gdyby okazało się, że hipoteza Gontarczyka, iż Nowotkę zabili Niemcy lub AK, jest prawdziwa, to NSZ-ZJ stanowiłaby jedyną dużą organizacją podziemna, której dowódca został zamordowany przez własnych podkomendnych. Zob. Nowotko-Mołojec: $Z$ poczatków PPR. Nieznane relacje Władysława Gomutki i Franciszka Jóźwiaka, Londyn 1986, s. 8-10; P. Gontarczyk, Polska Partia Robotnicza. Droga do wtadzy 1941-1944, Warszawa 2003, s. 153-62. 
Zjednoczenie wysiłku zbrojnego Polaków imię całości i późniejszej niepodległości Rzeczypospolitej było zawsze i jest elementarnym nakazem podyktowanym przez racje prawne, polityczne, wojskowe i moralne. W ostatnich czasach, w trakcie definitywnego scalania organizacji wojskowych w Kraju, doszło ze strony skrajnych czynników Narodowych Sił Zbrojnych do niedopuszczalnych wystapień godzących w zasady jedności wojska, subordynacji wojskowej i posłuszeństwa wobec prawa. Stwierdzam, że z mocy prawa Armia Krajowa jest jedynym wojskiem polskim na terenie Kraju. Wszystkie organizacje o charakterze wojskowym, które pozostaja poza nią, nie podlegając jej Komendantowi Głównemu, a przez to samo władzom legalnym Rzeczypospolitej Polskiej w Kraju, obowiązanym do spełnienia powinności wojskowej - należenia do jakichkolwiek bądź organizacji wojskowych poza Armia Krajową i nakazuję, aby bez zwłoki podporządkowali się rozkazom Komendanta Głównego Sił Zbrojnych w Kraju (Armii Krajowej) ${ }^{118}$.

Miesiąc później rząd RP na uchodźstwie uznał, iż oenerowcy dążą do „rozbicia Armii Krajowej i nie cofają się przed mordami bratobójczymi”. Działania NSZ-ZJ określił mianem ,zbrodni” i zapowiedział, „że wszyscy winni bezpośrednio lub pośrednio tej działalności będą ścigani z całą surowościa prawa"119.

Tym samym najważniejsze cywilne i wojskowe instytucje państwa polskiego uznały, iż działania NSZ-ZJ godzą w polską rację stanu, i zapowiedziały postawienie przed sądem osób za to odpowiedzialnych. Oenerowcy znaleźli się poza politycznymi i wojskowymi strukturami państwa polskiego. Ich sytuacja formalnoprawna i polityczna była więc identyczna z położeniem polskich komunistów. NSZ-ZJ, tak samo jak GL-AL, nie włączyły się do PSZ, oenerowska Grupa „Szańca”, podobnie jak PPR, nie weszła do porozumienia stronnictw politycznych, na których opierał się rząd polski na uchodźstwie, ani do Rady Jedności Narodowej (RJN) - podziemnego parlamentu.

Spójrzmy na scalenie z perspektywy Komendanta Głównego AK. Latem 1944 r. tylko jeden okręg NSZ w całości przeszedł do NSZ-ZJ, a w pięciu kolejnych oenerowcy zdobyli większe lub mniejsze wpływy. Zdecydowana większość członków NSZ uznała zwierzchność Komendanta Sił Zbrojnych w Kraju. Można więc mówić o sukcesie organizacyjnym owocującym zauważalnym wzmocnieniem potencjału AK. Należy jednocześnie pamiętać, że ważnym celem scalenia było doprowadzenie do sytuacji, w której polscy komuniści mieliby przeciwko sobie występujące $\mathrm{w}$ jednym bloku wszystkie siły polityczne stojące na gruncie polskiej suwerenności. Stąd dążenie gen. Komorowskiego do włączenia do AK zarówno wywodzącej się ze ZJ skrajnie prawicowej części NSZ, jak i radykalnie lewicowej PAL. Utworzenie NSZ-ZJ oznaczało, że próba realizacji tego planu zakończyła się porażką.

118 SPP, A 434, NSZ, Odezwa Naczelnego Wodza gen Sosnkowskiego, pismo Nr 1.1205, k 49.

119 Ibidem, Pismo z 31 VII 1944 r., zaadresowane „Komendant Armii Krajowej”, sygnowane Prezes Rady Ministrów w.z. Jan Kwapiński, k. 50. Jan Kwapiński pełnił wówczas funkcję wicepremiera w rządzie Stanisława Mikołajczyka. 
Przywódcy NSZ-ZJ mieli jeszcze mniej powodów do zadowolenia. Utracili wpływy w terenie, ugruntowali opinię środowiska brutalnego, niegodnego zaufania i niezdolnego do kompromisu, w efekcie znaleźli się w całkowitej izolacji politycznej. Zdołali natomiast utrzymać kontrolę nad relatywnie niewielka, za to połączoną silnymi więzami ideologicznymi, grupa konspiratorów i partyzantów.

Krytycznie nastawieni do planu wywołania powstania w Warszawie, liderzy NSZ-ZJ na wieść o jego rychłym wybuchu zdecydowali się na opuszczenie stolicy. 29 VII 1944 r. większość z nich wyjechała pociagiem do Częstochowy, gdzie stworzyli nacjonalistyczny ośrodek polityczno-wojskowy. Gdy okazało się, że AK nie zdołała samodzielnie wyswobodzić Warszawy, Armia Czerwona zaś nie zamierza przyjść na odsiecz powstańcom, podjęli oni próbę przechwycenia kierownictwa nad podziemiem. W prasie NSZ-ZJ ogłoszono powstanie Rady Narodowej Polski. Oenerowcy, by nadać działaniom wagi, odwołali się do powszechnie rozpoznawalnych symboli: „Zgodnie z najszczytniejszymi tradycjami Narodu Polskiego przedstawiciele Rady Narodowej Polski, pomimo istniejących trudności komunikacyjnych, dotarli 15 sierpnia br., w dzień Matki Boskiej Królowej Korony Polskiej do Częstochowy, gdzie pod Cudownym Obrazem zwrócili się o opiekę i błogosławieństwo dla swych prac do Tej, która była zawsze i będzie Orędowniczką Narodu Polskiego" ${ }^{120}$. Głosili też, jakoby działali z ramienia rządu RP w Londynie, pozostawali w stałym z nim kontakcie i przejmowali kompetencje RJN i Delegatury Rządu na Kraj. Oenerowcy twierdzili, iż Rada Narodowa Polski ma pluralistyczny charakter. Podjęli nawet zakończoną niepowodzeniem próbę wciagnięcia w orbitę swych wpływów miejscowych członków SN, Stronnictwa Pracy i Polskiej Partii Socjalistycznej. Instytucje PPP zareagowały szybko i zdecydowanie. Kielecka okręgowa Delegatura Rządu wydała oświadczenie potępiające „destrukcyjne i szkodliwe" działania liderów NSZ-ZJ'121. Krakowska okręgowa Delegatura Rządu opublikowała zaś tekst stwierdzający, że ONR to formacja

stojąca daleko poza najprymitywniejszym pojęciem etyki politycznej, wybitnie szkodliwa dla interesów polskich, nie przebiera w środkach, aby dojść do wytyczonego celu, tzn. do zaprowadzenia w Polsce rządów faszystowskich. Wśród bogatego repertuaru jej metod nie brak spółki z elementami pospolitych przestępców kryminalnych, szantaży i innych środków, które ONR dyskwalifikuja pod każdym względem. [...] wobec faktu, że w Warszawie działa w dalszym ciagu Pełnomocnik Rządu i Rada Jedności Narodowej, utworzenie jakiejś samozwańczej Rady Narodowej jest typowa robota zmierzająca do zdezorganizowania społeczeństwa polskiego, tym bardziej zbrodnicza, że uzurpująca sobie oficjalny charakter reprezentacji narodu polskiego. Ten również cel miało upodobnienie graficzne pisma ONR do „Rzeczypospolitej” wychodzącej w Warszawie, aby stworzyć „optyczne” pozory, że częstochowska Rada Narodowa jest kontynuacja Delegatury warszawskiej ${ }^{122}$.

\footnotetext{
120 „Przegląd Narodowy” 1944, nr 5.

121 B. Wójcik, op. cit.

122 „Kurier Powszechny” 1944, nr 11.
} 
O sprawie w wysłanej na początku października depeszy informował Londyn Okręg Radomsko-Kielecki AK. Czytamy w niej: „W Częstochowie zorganizowana została przez ONR korzystająca z odcięcia od kraju od Rady Jedności Narodowej i z b. Rada Narodowa notyfikowała w wyd. «Rzeczpospolita Polska» i "Przegląd Narodowy», nie znalazła poparcia w żądnym ze stronnictw politycznych uważana jest za dywersyjny akt polityczny"123.

Próba podszycia się pod instytucje PPP, przejęcia ich kompetencji i przechwycenia władzy nad podziemiem spaliła na panewce. Oenerowscy przywódcy musieli pogodzić się z fiaskiem projektu narodowej rewolucji, w której wyniku władzę w Polsce sprawować miałaby monopartyjna dyktatura nacjonalistów. Skonfliktowani ze SN, otwarcie wrodzy prodemokratycznym partiom PPP, odpowiedzialni za mordy polityczne na komunistach, w obliczu nadciagającej Armii Czerwonej stanęli przed wyborem: pozostać w kraju i działać w antykomunistycznym podziemiu czy uciekać na Zachód. Wybrali to ostatnie. Niemal całe polityczne kierownictwo NSZ-ZJ przyłączyło się do Brygady Świętokrzyskiej NSZ i z nia, za przyzwoleniem i z pomoca Niemców, opuściło Polskę.

Gdy w połowie 1945 r. Brygada Świętokrzyska znalazła się w amerykańskiej strefie okupacyjnej, jej dowództwo podawało się za oddział AK i wydało członkom jednostki legitymacje z nadrukiem „Armia Polska Brygada Świętokrzyska”, informujące jakoby ich posiadacze byli żołnierzami polskimi w służbie czynnej ${ }^{124}$. Wysłannicy PSZ na Zachodzie szybko zorientowali się, że jednostka podszywa się pod oddział AK, bezprawnie używa nazwy Armia Polska, a na jej dowódcach ciąża poważne oskarżenia ze strony Komendanta Głównego AK i przywódców PPP. Wobec sprzeciwu władz polskich i brytyjskiego Ministerstwa Wojny Brygada Świętokrzyska NSZ nie została włączona do PSZ na Zachodzie ${ }^{125}$. Jej członkowie wstapić do nich mogli jedynie na zasadzie indywidualnego akcesu. Działająca przy PSZ komisja weryfikacyjna nie uznawała członkostwa w NSZ-ZJ i Brygadzie Świętokrzyskiej za służbę w WP. Członkom tych formacji z zasady odmawiano nadania uprawnień kombatanckich przyznawanych żołnierzom AK.

$\mathrm{Na}$ Zachodzie środowisko NSZ-ZJ w pierwszym okresie powojennym otaczał swoisty „kordon sanitarny”. Ostracyzm stopniowo ulegał osłabieniu, do czego przyczyniały się naturalne biologiczne procesy, w których wyniku odchodzili wyżsi stopniem oficerowie PSZ i AK, mający szerszy ogląd sprawy i jednoznacznie negatywny osąd działań NSZ-ZJ. Wśród politycznie aktywnych emigrantów spory wojenne z czasem traciły na znaczeniu. Wspólny dla większości ówczesnej polskiej emigracji antykomunizm był zaś płaszczyzna, na której mogli się spotkać ludzie wywodzący się z różnych tradycji, od

\footnotetext{
${ }^{123}$ SPP, A 434, NSZ, Depesza z Okręg Kielce-Radom AK do Centrali, 4 X 1944, k. 51.

${ }^{124}$ Egzemplarz legitymacji w: SPP, A 434, NSZ, k. 154.

${ }^{125}$ Cz. Brzoza, Od Miechowa do Coburga. Brygada Świętokrzyska Narodowych Sit Zbrojnych w marszu na zachód, „Pamięć i Sprawiedliwość” 2004, nr 5, s. 258-264.
} 
socjalistów po nacjonalistów. Wieloletnie zabiegi oenerowców, mające na celu osłabienie politycznego i środowiskowego wykluczenia, zaczęły z czasem przynosić wymierne efekty. W końcu w 1988 r. prezydent RP na uchodźstwie Kazimierz Sabat wydał dekret głoszący, iż „Żołnierze tej części Narodowych Sił Zbrojnych która ze względu na stanowisko jej części kierowniczych nie została scalona z Polskimi Siłami Zbrojnymi - Armią Krajową i którzy brali udział w walkach z okupantami w latach 1939-1945 spełnili swój obowiązek narodowy i żołnierski wobec Rzeczypospolitej Polskiej”"126. Po 43 latach przebywajacy na emigracji członkowie NSZ-ZJ i Brygady Świętokrzyskiej NSZ przełamali izolację polityczna. Oenerowscy liderzy nie zdołali jednak uzyskać dla swej „wojskówki” statusu kombatantów - żołnierzy WP.

\section{Streszczenie}

W wyniku trwającego pięć lat procesu do Sił Zbrojnych w Kraju weszły niemal wszystkie liczące się formacje zbrojne. Poza Armią Krajową pozostały jedynie Gwardia Ludowa-Armia Ludowa i część Narodowych Sił Zbrojnych wywodząca się z Obozu Narodowo-Radykalnego ABC (Narodowe Siły Zbrojne-Związek Jaszczurczy - NSZ-ZJ). Przyczyny wrogości Polskiej Partii Robotniczej i ich bojówki GL-AL wobec władz polskich na uchodźstwie Polskiego Państwa Podziemnego (PPP), a co za tym idzie, akcji scaleniowej zostały w literaturze przedmiotu stosunkowo dobrze opisane. Inaczej jest z NSZ-ZJ. Autorów istniejących opracowań interesowały głównie procesy zachodzace wewnątrz ruchu narodowego. Niniejszy artykuł stanowi próbę zmiany tej perspektywy i ukazuje scalenie narodowej „wojskówki” z AK z punktu widzenia funkcjonujących $\mathrm{w}$ kraju i na uchodźstwie instytucji państwa polskiego. Autor odpowiadając na pytanie, dlaczego NSZ-ZJ nie została częścią Sił Zbrojnych w Kraju, dochodzi do wniosku, że stało się tak z powodu splotu przyczyn ideologicznych (wrogość liderów ONR ABC do demokracji, pluralizmu i parlamentaryzmu), psychologicznych (ambicje narodowo-radykalnych przywódców, brak zaufania między stronami negocjujacymi scalenie) i fundamentalnego konfliktu celów (narodowi radykałowie dążyli do narodowej rewolucji, PPP zaś do restytucji II RP).

\section{Unfinished Consolidation. Attempts to Incorporate the National Armed Forces into the Home Army}

After a five-year process, the Home Army absorbed most of the major military formations. Only the People's Guard-People's Army and a part of National Armed Forces, originating from the ABC National-Radical Camp (National Armed Forces-the Lizard Union - NSZ-ZJ) remained

126 SPP, A 434, NSZ, Dekret prezydenta Rzeczypospolitej Kazimierza Sabata z dnia 1 stycznia 1988 roku o żołnierzach Narodowych Sił Zbrojnych, k. 180. Decyzja prezydenta Sabata była odpowiedzią na „Deklarację braterstwa broni” ogłoszoną w Amerykańskiej Częstochowie 2 VIII 1987 r. przez grupę żołnierzy AK i Brygady Świętokrzyskiej NSZ. W dokumencie tym zwracali się oni do prezydenta, by położył on kres „ostracyzmowi” wobec żołnierzy NSZ, a szczególnie Brygady Świętokrzyskiej, gdyż „AK nie przynosi ona zaszczytu”. Zob. ibidem, Deklaracja braterstwa broni, sygnował B. Mark-Nadolczyk ppłk-spad. CC, przewodniczący Dnia Żołnierza Polski Podziemnej, k. 179. 
outside the HA. The reasons for the hostility of the Polish Workers' Party and their armed group GL-AL towards the authorities in exile of the Polish Underground State (PPP), and thus towards the consolidation, have been relatively well described in the literature on the subject. It is different in the case of NSZ-ZJ. The authors of published studies were mainly interested in the processes occurring within the national movement. This article attempts to change this perspective and presents the consolidation of the national formation with the Home Army from the perspective of the institutions of the Polish state operating in the country and in exile. Answering the question, why the NSZ-ZJ did not become a part of the Home Army, the author concludes that it was due to a combination of ideological reasons (hostility of the ABC National-Radical Camp leaders to democracy, pluralism, and parliamentarism), psychological reasons (ambitions of the national-radical leaders, and the lack of trust between the parties negotiating the consolidation), and a fundamental conflict of goals (national radicals aimed at a national revolution, while the PPP leaders strove for the restitution of the Second Republic of Poland).

\section{Bibliografia}

Bór-Komorowski T., Armia Podziemna, Londyn 1952.

Brzoza Cz., Od Miechowa do Coburga. Brygada Świętokrzyska Narodowych Sit Zbrojnych w marszu na zachód, „Pamięć i Sprawiedliwość” 2004, nr 5, s. 221-274.

Gniadek-Zieliński M., Narodowe Sity Zbrojne 1942-1947, Warszawa 2017.

Gontarczyk P., Polska Partia Robotnicza. Droga do wtadzy 1941-1944, Warszawa 2003.

Iłłakowicz J.O., O Narodowych Siłach Zbrojnych, „Zeszyty Historyczne” 1986, z. 76, s. 90-113.

Komorowski K., Jeden z „Szesnastu”: okupacyjny watek biografii Zbigniewa Styputkowskiego, „Niepodległość i Pamięć” 2017, nr 1 (57), s. 13-54.

Komorowski K., Polityka i walka. Konspiracja zbrojna ruchu narodowego 1939-1945, Warszawa 2000.

Muszyński W.J., Duch młodych. Organizacja Polska i Obóz Narodowo-Radykalny w latach 1934-1944. Od studenckiej rewolty do konspiracji niepodległościowej, Warszawa 2011.

Siemaszko Z.S., Narodowe Sity Zbrojne, Londyn 1982.

Terej J.J., Rzeczywistość i polityka. Ze studiów nad dziejami najnowszymi Narodowej Demokracji, Warszawa 1979.

Wójcik B., ONR gra va banque. Zapomniany epizod schytku okupacji, http://ohistorie. eu/2018/09/28/626/ (dostęp: 6 I 2020).

Żochowski S., O Narodowych Siłach Zbrojnych. NSZ, Lublin 1994.

Rafał Wnuk - prof. dr hab., Katolicki Uniwersytet Lubelski. Obecnie badania koncentruje na wojennej i powojennej konspiracji i partyzantce w Europie Środkowo-Wschodniej oraz problemie pamięci kulturowej. E-mail: ravwnuk22@gmail.com.

Rafal Wnuk - Prof. Dr. hab., the John Paul II Catholic University of Lublin. His current research focuses on war and post-war underground and guerrilla warfare in Central and Eastern Europe, and the problem of cultural memory. E-mail: ravwnuk22@gmail.com. 